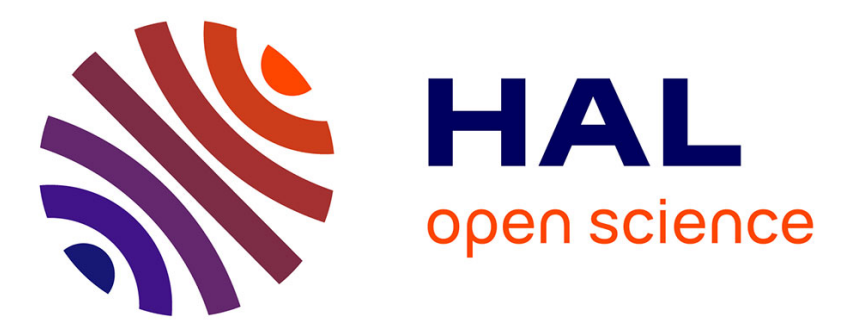

\title{
Dust emission and transport over Iraq associated with the summer Shamal winds
}

\author{
Diana Bou Karam, Cyrille Flamant, Jean-Pierre Chaboureau, Jamie R. \\ Banks, Juan Cuesta, Helen Brindley, L. Oolman
}

\section{To cite this version:}

Diana Bou Karam, Cyrille Flamant, Jean-Pierre Chaboureau, Jamie R. Banks, Juan Cuesta, et al.. Dust emission and transport over Iraq associated with the summer Shamal winds. Aeolian Research, 2017, 24, pp.15-31. 10.1016/j.aeolia.2016.11.001 . insu-01412905

\section{HAL Id: insu-01412905 https://hal-insu.archives-ouvertes.fr/insu-01412905}

Submitted on 31 Aug 2021

HAL is a multi-disciplinary open access archive for the deposit and dissemination of scientific research documents, whether they are published or not. The documents may come from teaching and research institutions in France or abroad, or from public or private research centers.
L'archive ouverte pluridisciplinaire HAL, est destinée au dépôt et à la diffusion de documents scientifiques de niveau recherche, publiés ou non, émanant des établissements d'enseignement et de recherche français ou étrangers, des laboratoires publics ou privés. 


\title{
Dust emission and transport over Iraq associated with the summer Shamal winds
}

\author{
D. Bou Karam Francis ${ }^{\mathrm{a}, \mathrm{b}}$, C. Flamant ${ }^{\text {b }}$, J.-P. Chaboureau ${ }^{\text {c }}$, J. Banks ${ }^{\mathrm{d}}$, J. Cuesta ${ }^{\mathrm{e}}$, H. Brindley ${ }^{\mathrm{d}}$, L. Oolman ${ }^{\mathrm{f}}$ \\ ${ }^{\text {a }}$ Centre for Sea Level Change, New York University Abu Dhabi, Abu Dhabi, United Arab Emirates \\ ${ }^{\mathrm{b}}$ LATMOS/IPSL, UPMC Univ. Paris 06 Sorbonne Universités, UVSO CNRS, Paris, France \\ ${ }^{\mathrm{c}}$ Laboratoire d'Aérologie, Université of Toulouse and CNRS, Toulouse, France \\ ${ }^{\mathrm{d}}$ Space and Atmospheric Physics Group, Imperial College, London, UK \\ ${ }^{\mathrm{e}}$ Laboratoire Interuniversitaire des systèmes atmosphériques, CNRS and Université Paris-Est Créteil Val de Marne, France \\ ${ }^{\mathrm{f}}$ Department of Atmospheric Science, University of Wyoming, Laramie, WY, USA
}

\begin{abstract}
In this study, we investigate the diurnal evolution of the summer Shamal wind (a quasi-permanent lowlevel northwesterly wind feature) and its role in dust emission and transport over Iraq, using groundbased and space-borne observations together with a numerical simulation performed with the mesoscale model meso-NH. A 6-year dataset from the synoptic stations over Iraq allows establishing the prominence of the link between strong near surface winds and reduced visibility in the summer. The detailed processes at play during Shamal events are explored on the basis of a meso-NH simulation for a given, representative case study (25 June-3 July 2010). The Shamal exhibits an out-of-phase relationship between the surface wind and winds in the lower troposphere (typically $500 \mathrm{~m}$ above ground level), the maximum surface wind speeds being observed during the day while in altitude the maximum wind speeds are observed at night. The daytime near surface winds, at the origin of dust emission, are associated with the downward transfer of momentum from the nocturnal low-level jet to the surface due to turbulent mixing after solar heating commences each day. For the first time, an estimate of the dust load associated with summer Shamal events over Iraq has been made using aerosol optical depths derived from the Spinning Enhanced Visible and Infrared Imager, the Moderate Resolution Imaging Spectroradiometer, and the simulation. The dust load exhibits a large diurnal variability, with a daily minimum value of $1 \mathrm{Tg}$ around $0600 \mathrm{UTC}$ and a daily peak of $2.5 \mathrm{Tg}$ or more around $1500 \mathrm{UTC}$, and is driven by the diurnal cycle of the near surface wind speed. The daily dust load peak associated with the summer Shamal over Iraq is in the same order of magnitude as those derived from simulations downstream of the Bodéle depression in Chad, known to be the world's largest dust source.
\end{abstract}

\section{Introduction}

While analyzing the dynamical processes responsible for dust emission over Iran and surrounding countries, as well as the subsequent transport of dust toward northwest Iran, Abdi Vishkaee et al. $(2011,2012)$ have shown the prevalent influence of Shamal winds for dust mobilization in both summer and winter. The "Shamal" names strong northwesterly winds blowing over Iraq and in the Persian Gulf area during the summer (June to September) and the winter (November to March) (Perrone, 1979). While the summer Shamal blows almost continuously, winter Shamal events occur two to three times per month between December and early March (Rao et al., 2001a).
The summer Shamal blowing over Iraq and the Persian Gulf exhibits an out-of-phase relationship between the surface wind and winds in the lower troposphere (typically 300-700 m above ground level, agl), the maximum surface wind speeds being observed during the day while, above, the maximum wind speeds are observed at night. This night-time feature is what we call nocturnal low-level jet (LLJ) (Membery, 1983). This Shamal-related LLJ is primarily a thermal phenomenon which has recently been analyzed by Giannakopoulou and Toumi (2011) using mesoscale simulations. They show that the Blackadar (1957) mechanism appears to be secondary to the heating in forcing the LLJ. It has been well established in other parts of the world, notably Africa, that dust emissions over potential source areas (e.g. Kok et al. (2012)) are 
related to surface wind speed maxima which occur in the hours after sunrise (e.g. the example of the Bodéle depression; Washington and Todd, 2005). The phase shift in the diurnal cycle of the LLJ and surface winds is associated with the downward transfer of momentum from the nocturnal LLJ to the surface due to turbulent mixing after solar heating commences each day (Todd et al., 2008).

Dust events associated with summer Shamal can reduce visibilities to a few hundred meters (e.g. Rao et al. (2001a), Abdi Vishkaee et al. (2011)). The link between the formation of the low level jet, maximum surface winds and reduced visibilities due to dust mobilization in Iraq and the northern Persian Gulf has been highlighted by Wilkerson (1991). A description of the major climatic controls, mesoscale synoptic features, and the influence of topography that lead to the formation of the summer Shamal, the low level jet and dust mobilization in the Persian Gulf region can be found in Walters and Sjoberg (1988). Moreover, dust mobilization in Iraq has broader impacts than the local ones and can affect the entire Arabian Peninsula (e.g. Notaro et al. (2013)). For instance, Notaro et al. (2015) has demonstrated that the long-term drought and increased dust emission from Iraq largely contributes to the recent increase in dust activity across the Arabian Peninsula. Also, dust from Iraq associated with summer Shamal winds largely regulates the interannual variability in summertime dust activity across Saudi Arabia (Yu et al., 2015).

The first objective of this paper is to analyze the impact of the diurnal evolution of the summer Shamal winds on the dust emissions and transport over Iraq, using data from existing synoptic stations, satellite observations including the newly available aerosol optical depth (AOD) product from the Spinning Enhanced Visible and Infrared Imager (SEVIRI) over this region and a numerical simulation performed with the mesoscale model meso- $\mathrm{NH}$. The second objective is to provide a quantitative estimate of dust emissions and concentrations over Iraq during such an event on the basis of the meso-NH simulation and satellite-derived AODs for a representative case study (25 June-3 July 2010).

The paper is organized as follows: In section 2, the datasets utilized in this study are introduced. Section 3 gives an overview of the dust sources in Iraq. In Section 4 we show evidence of the link between strong Shamal winds and low surface visibility using a 6year dataset of SYNOP stations in Iraq and Iran. Section 5 details the case study and give an estimate of the dust loads associated with Shamal-induced dust emissions based on space-borne observations and meso-NH numerical simulation. Section 6 provides a summary and conclusions.

\section{Data}

\subsection{Regional networks}

We use meteorological measurements provided by stations in Balad, Mosul and Tallil (Iraq) as well as Abadan (Iran) (see Fig. 1 and Table 1, available from http://weather.uwyo.edu/) for the period 2005-2010. These stations report 3-hourly surface data including pressure, temperature, humidity, and wind speed and direction. The visibility observations in Iraq are taken by observers looking at landmarks (also see Abdi Vishkaee et al. (2012) for further discussion on this). In this paper, dust storms are considered to be associated with visibility values of $3.5 \mathrm{~km}$ or less, as in Liu et al. (2007) and Walker et al. (2009) for the same region. For a given station, this threshold value on visibility allows to account for both strong dust events occurring near dust source regions in Iraq (characterized by visibilities less than $1 \mathrm{~km}$, Middleton (1986b)) and events resulting from long-range transports (for which visibilities are in the range $2-9 \mathrm{~km}$, e.g. Mahowald et al.
(2007)). In the case of propagating dust storms, the arrival of airborne dust at a given site is generally associated with a significant decrease in visibility and increase in wind speed.

\subsection{Space-borne observations}

The distribution of dust aerosols at regional scale (mobilization and transport) is described using three satellite products. The Moderate Resolution Imaging Spectroradiometer (MODIS) fields of AOD are obtained from the MODIS/AQUA MYD08 (collection D3.051) daily level 3 products. Two AOD products at $550 \mathrm{~nm}$ are used: the AOD processed with deep blue algorithm (Hsu et al., 2004) over desert surfaces and the standard product processed over dark surfaces. Both are available from the Giovanni Web portal (http://disc.sci.gsfc.nasa.gov/giovanni). We use the level 3, gridded $\left(1^{\circ} \times 1^{\circ}\right)$ daily products, representative of the aerosol load around $1: 30 \mathrm{am} / \mathrm{pm}$ equator crossing time. Sayer et al. (2013) and Banks et al. (2013) have shown that AODs derived from Deep Blue AQUA collection 6 data compared well with AERONET (generally within 20-25\%) over the Sahara and the Arabian Peninsula. The uncertainty estimate for MODIS Deep blue Collection is in the order of \pm 0.2 as detailed in Sayer et al., 2013.

In this paper, satellite observations of dust over Iraq have been made, for the first time, using SEVIRI in geostationary orbit aboard Meteosat-9 (Schmetz et al., 2002) above $0^{\circ} \mathrm{N} / 0^{\circ} \mathrm{E}$. SEVIRI provides observations every $15 \mathrm{~min}$ in 11 channels in the visible and infared. At nadir, the spatial sampling rate is $3 \mathrm{~km}$, over Iraq this increases to $\sim 5.5 \mathrm{~km}$. Iraq is towards the limb of SEVIRI's fieldof-view, so over much of the country the viewing zenith angles are greater than $60^{\circ}$. SEVIRI AOD retrievals over desert and arid regions (Brindley and Russell, 2009; Banks and Brindley, 2013) are attempted where the solar and viewing zenith angles are less than $70^{\circ}$, so over Iraq the last measurements each day are made at 1400 UTC. Dust AOD retrievals are made in a three-stage process, starting by screening pixels as being dusty and/or cloudy (Derrien and Le Gléau, 2005). The next step is to calculate a 'pristine-sky' (Brindley, 2007) value of the brightness temperature at $10.8 \mu \mathrm{m}$ ( $\left.\mathrm{T}_{\mathrm{B} 108 \mathrm{dfe}}\right)$ for each timeslot, and hence to calculate the instantaneous variation $\Delta \mathrm{T}_{\mathrm{B} 108}$ from the pristine-sky values. Adjustments are made to account for variability in the column water vapour and skin temperature, which will also impact on the observed brightness temperature. Finally, the AOD at $550 \mathrm{~nm}$ at the pixel-scale is derived using a simulated relationship between $\Delta \mathrm{T}_{\mathrm{B} 108 /} / \Delta \mathrm{T}_{\mathrm{B} 134}$ and AOD (Brindley and Russell, 2009). Validation against AERONET measurements from six sites over a three-year period indicates that root-mean-square differences vary from 0.19 to 0.46 (Banks and Brindley, 2013). Banks et al., 2013 estimated the uncertainty associated with SEVIRI AODs retrievals over the study area to be on the order of \pm 0.1 .

Finally, the vertical distribution of the aerosols is documented over the Persian Gulf region using the space-borne Cloud-Aerosol Lidar with Orthogonal Polarization (CALIOP) (Winker et al., 2007) on board the Cloud-Aerosol Lidar and Infrared Pathfinder Satellite Observations (CALIPSO) satellite. CALIOP-derived profiles of particle extinction coefficient (at $532 \mathrm{~nm}$ ) are obtained from our own calculation (using level 1B version 3.01 data) as that by Cuesta et al. (2009), with a vertical resolution of $60 \mathrm{~m}$ and a horizontal resolution of roughly $12 \mathrm{~km}$. We expect the uncertainty on the extinction coefficient and on the AOD to be on the order of $30 \%$ (and may be greater for AOD greater than 2), accounting for an uncertainty of $20 \%$ on both the backscatter-to-extinction ratio and the multiple scattering coefficients. Data from two daytime overpasses are used to analyze the case: on 30 June 2010 and on 2 July 2010 . The data is available through the ICARE Web portal (http://www.icare.univ-lille1.fr). 

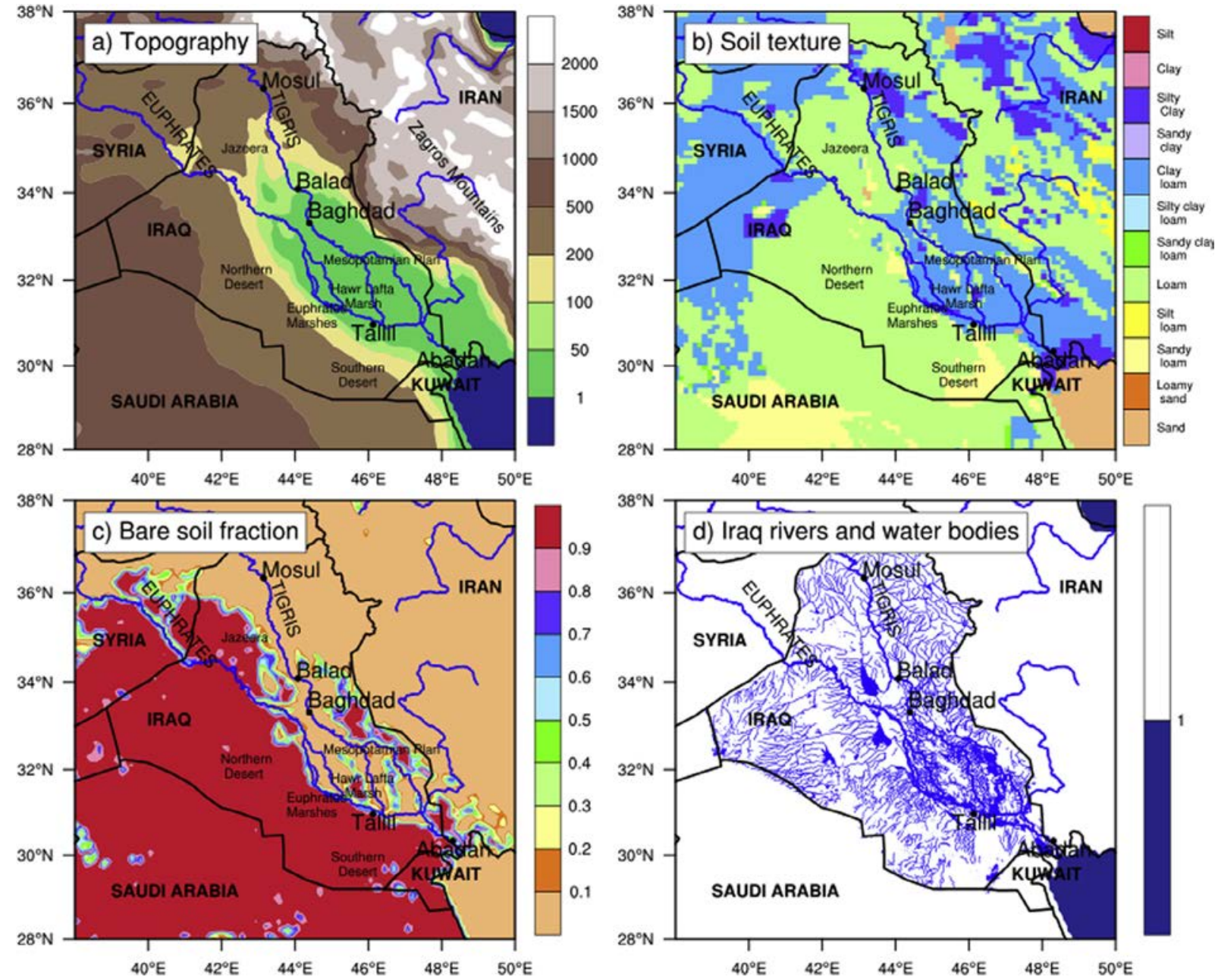

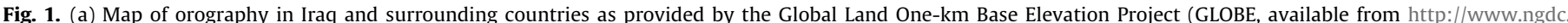

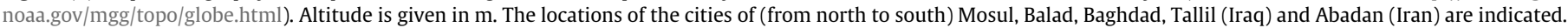
(b) Soil texture determined according to Mokhtari et al. (2012). (c) Fraction of bare soil over Iraq and surrounding countries. (d) Rivers and Water bodies in Iraq.

Table 1

List of SYNOP stations used in this study (from north to south).

\begin{tabular}{llll}
\hline Station & Position (Latitude, Longitude) & Station code & Altitude $(\mathrm{m})$ \\
\hline Mosul (Iraq) & $43.14^{\circ} \mathrm{E}, 36.33^{\circ} \mathrm{N}$ & KQTU & 216 \\
Balad (Iraq) & $44.08^{\circ} \mathrm{E}, 34.09^{\circ} \mathrm{N}$ & KQTO & 49 \\
Tallil (Iraq) & $46.13^{\circ} \mathrm{E}, 30.97^{\circ} \mathrm{N}$ & KQXJ & 6 \\
Abadan (Iran) & $48.25^{\circ} \mathrm{E}, 30.37^{\circ} \mathrm{N}$ & OIAA & 3
\end{tabular}

\subsection{Meso-NH simulation}

The numerical simulation was made with the research model meso-NH (Lafore et al., 1998) version 4.7. The model domain (Fig. 2) had a grid mesh of $12 \mathrm{~km}$ and 70 vertical levels distant by $60 \mathrm{~m}$ close to the surface and distant by $600 \mathrm{~m}$ in the free troposphere. Operational ECMWF analyses were used as lateral boundaries while a four-day meso-NH run nudged towards the ECMWF analyses provided the initial conditions including the dust fields. The simulation was run for 10 days starting at 0000 UTC 25 June. The model included a convective mass-flux scheme (Bechtold et al., 2001a), a mixed-phase bulk microphysical scheme (Pinty and Jabouille, 1998), a subgrid cloud cover and condensate content scheme (Chaboureau and Bechtold, 2002, 2005), a turbulence parameterization (Cuxart et al., 2000), the Rapid Radiative Transfer Model parameterization (Mlawer et al., 1997) that takes into account the radiative effect of dust and a dust scheme (Grini et al., 2006). The later included the Dust Entrainment and Deposition (DEAD) scheme (Zender et al., 2003) that calculates dust fluxes from wind friction speeds and the ORganic and Inorganic Lognormal Aerosols Model (ORILAM: Tulet et al. (2005)) in which transport, dry and wet deposition, and radiative properties of the distribution of three dust particle size are parameterized.

The meso-NH model has been extensively validated over north and west Africa where dust uplift associated with LLJ dynamics are observed on a regular basis all year round. It has been validated using many "aerosol related" datasets acquired from groundbased platforms (Tulet et al., 2008; Todd et al., 2008; Mallet et al., 2009), airborne platforms (Bou Karam et al., 2008, 2009b; Crumeyrolle et al., 2011; Schepanski et al., 2012) and spaceborne platforms (Bou Karam et al., 2009a, 2010, 2014; Chaboureau et al., 2011)). The fact that the processes of dust emission and transport over Iraq are similar to those observed in North Africa gives us confidence that the simulation of these processes by the meso-NH should be accurate even though we only have a limited dataset to compare it to.

\section{Overview of dust sources in Iraq and seasonality of dust source activation}

In Iraq, emissions can occur over a variety of surfaces and may be highly variable depending on the type of synoptic situation. For 

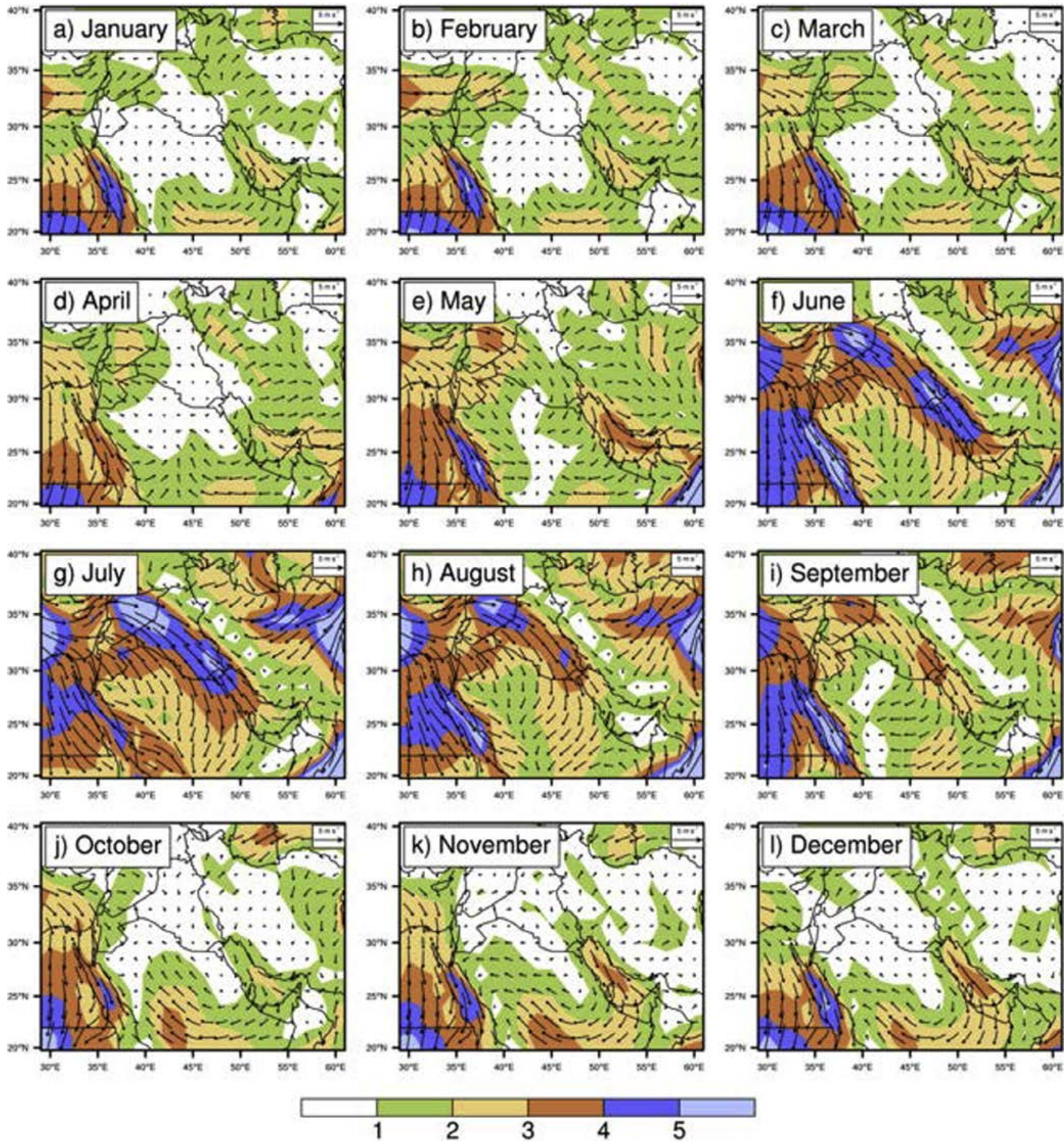

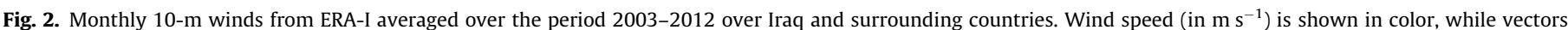
indicate wind direction.

instance, deserts occupy approximately $170,000 \mathrm{~km}^{2}$ and cover the western and southern part of the country as well as the Jazeera area (Fig. 1b and c). These large deserts contribute to the overall dust load over the country, even though Prospero et al. (2002) noted that the Total Ozone Mapping Spectrometer (TOMS) sensor does not show any substantial dust activity in these desert regions. According to Prospero et al. (2002), the most intense dust activity occurs south of $32^{\circ} \mathrm{N}, 200 \mathrm{~km}$ southeast of Baghdad. They have shown that dust activity in the Tigris-Euphrates basin is present all year round, reaches a maximum in July, and is much reduced by September-November. These sources are set in a vast alluvial plain located in the Mesopotamian Plan that extends southward from $100 \mathrm{~km}$ north of Baghdad to the Persian Gulf (Fig. 1d). The higher aerosol burdens during summer may be interpreted as a result of the combined effect of the seasonal drying of the numerous lakes and marshes and the strong northwesterly Shamal winds favoring dust erosion from the alluvial deposits in this region. These deposits cover approximately $130,000 \mathrm{~km}^{2}$.

The seasonality of near surface winds over Iraq can be seen in Fig. 2 which shows monthly 10-m winds from European Centre 
for Medium-range Weather Forecasts (ECMWF) ERA-Interim reanalysis (Dee et al., 2011) averaged for the period 2003-2012. In late spring and summer (Fig. 2e-i), strong surface winds are seen to blow across Syria, Iraq and over the Persian Gulf in connection with wind surges from the Mediterranean. Summer Shamal winds are quite frequent and are clearly discernible in monthly surface wind charts, particularly in June, July and August (Fig. 2f$\mathrm{h}$ ). The orography of the region appears to play a major role: for instance, the gap between the northern part of the elevated terrain to the west of the Arabic Peninsula and the Taurus Mountains in Turkey acts as a constriction, thereby accelerating the flow from the Mediterranean (see Fig. 1a). The general northwest southeast orientation of the Shamal flow results from the presence of high mountains of Turkey and Iran acting as a barrier for the impinging Mediterranean flow (Fig. 1a), as well as the upsloping terrain to the west and downsloping terrain to the south. In winter (Figs. 2ac and 11), a much weaker surface flow (on average) is seen over Syria and Iraq (due to the relatively small number of days with strong Shamal winds) while the strongest winds are seen over the Persian Gulf. In autumn (Fig. $2 \mathrm{j}$ and k) a weak surface flow (on average) is also seen over Syria and Iraq. Fig. 3 shows the monthly MODIS-derived AOD over the region, averaged for the period 2003-2012. It clearly shows large of AODs (in excess of 0.7 ) over Syria and Iraq during the spring and summer months (Fig. 3e-g), while rather weak AOD values are observed in the winter (Fig. 3a and J-1). In May, June and July, the largest AOD values
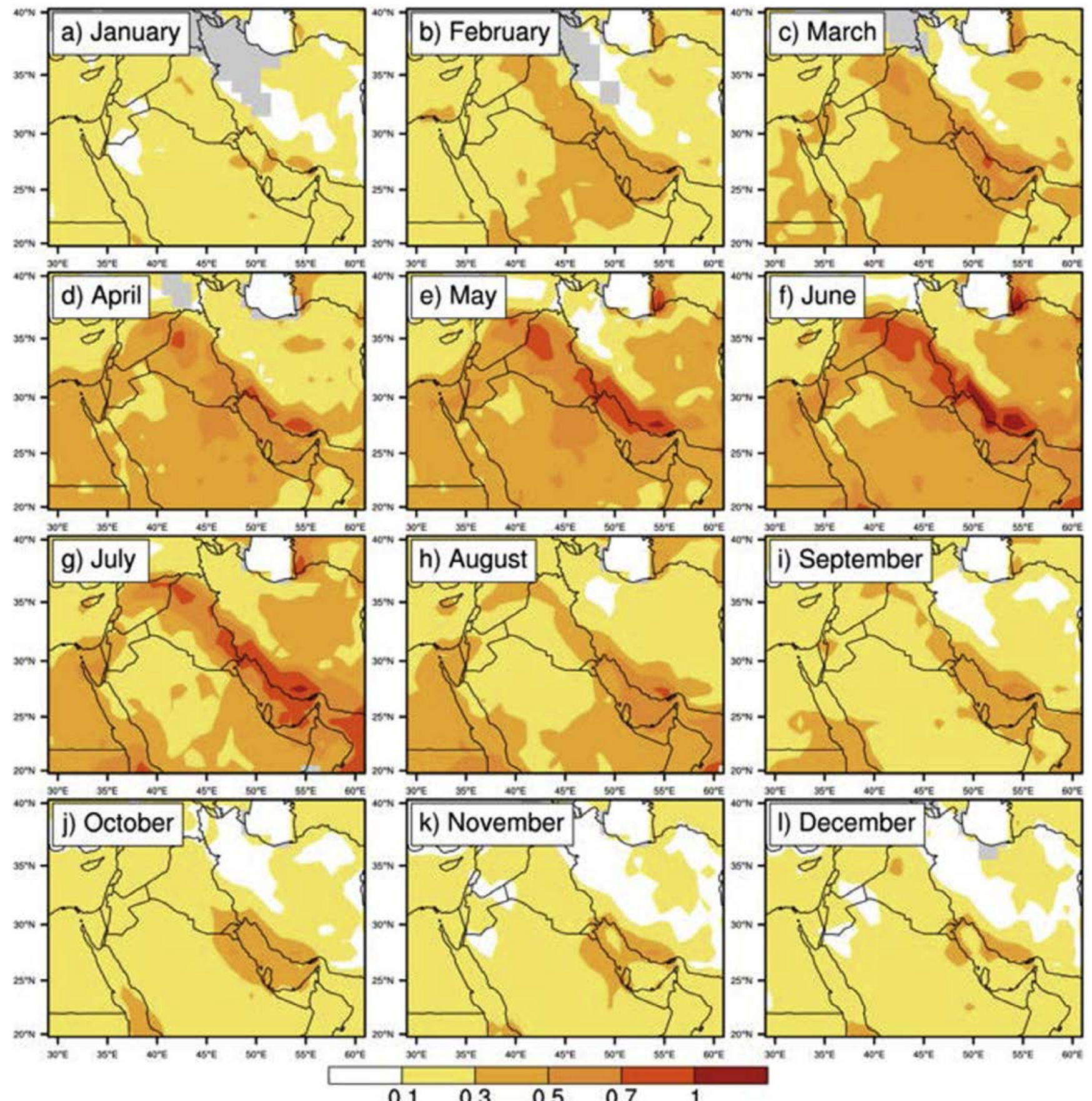

Fig. 3. Monthly fields of AOD (unit less) obtained from the MODIS/AQUA averaged over the period 2003-2012. 
are confined to the eastern part of Iraq, i.e. between the Euphrates and the foothills of the Zagros Mountains, as previously noted by Rao et al. (2001b). Furthermore, the MODIS dust maximum coincides with that of dust storm reports from meteorological stations (Middleton, 1986a,b). Middleton (1986b) reported an extremely high frequency of dust storms in this region, 43 per year at Abadan, making it one of the dustiest places in southwest Asia. The maximum AODs from MODIS are observed in June (Fig. 3f). We hypothesize that this is related to the number of Shamal events occurring during a given month in the summer (winter Shamal events being far less numerous than summer Shamal events) as well as the presence of a nocturnal LLJ over Iraq during the summer Shamal period.

This is now investigated using the 6-year dataset from the synoptic stations over Iraq. Fig. 4 shows the monthly distribution of the number of events for which the wind direction was from the $270^{\circ}-360^{\circ}$ sector, the wind speed was larger than $6 \mathrm{~m} \mathrm{~s}^{-1}$ and the visibility below $3.5 \mathrm{~km}$, in Mosul, Balad, Tallil and Abadan, for the period 2005-2010, as a function of the time of day (UTC, local time in Baghdad is UTC $+3 \mathrm{~h}$ ). Also shown is the time of sunrise and sunset in Baghdad. From the Tallil SYNOP observations (Fig. 4c), it can be seen that a significant number of events for high winds and low visibilities occur in late spring and throughout the summer (May-September). The largest numbers of events happen in June and July (100+ high wind speed events and 40+ low visibility events, respectively). A secondary maximum for the number of events for both high wind speeds and low visibilities is the month of March. It is also worth noting that for all months, the number of low visibility and high wind speed events occur at least one hour after sunrise and at least one hour before sunset (Fig. 4c), suggesting that these events are related to the diurnal evolution of the turbulence in the planetary boundary layer (PBL). Similar distributions of events were also obtained for different thresholds on wind speed and surface horizontal visibility (not shown).

All SYNOP stations south of Mosul exhibit the typical maximum number of high wind speed and low visibility events between sunrise and sunset in the spring and summer indicating that dust emissions over Iraq are related to surface wind speed maxima which occur in the hours after sunrise as the result of the down- (a)

(c)

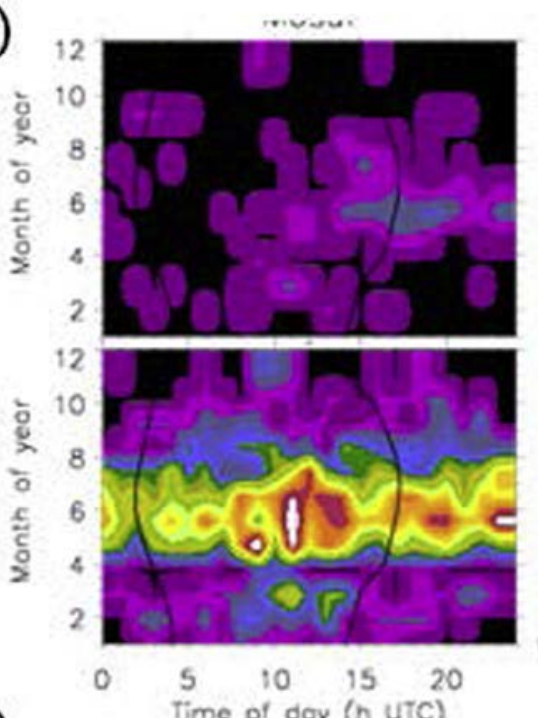

(b)
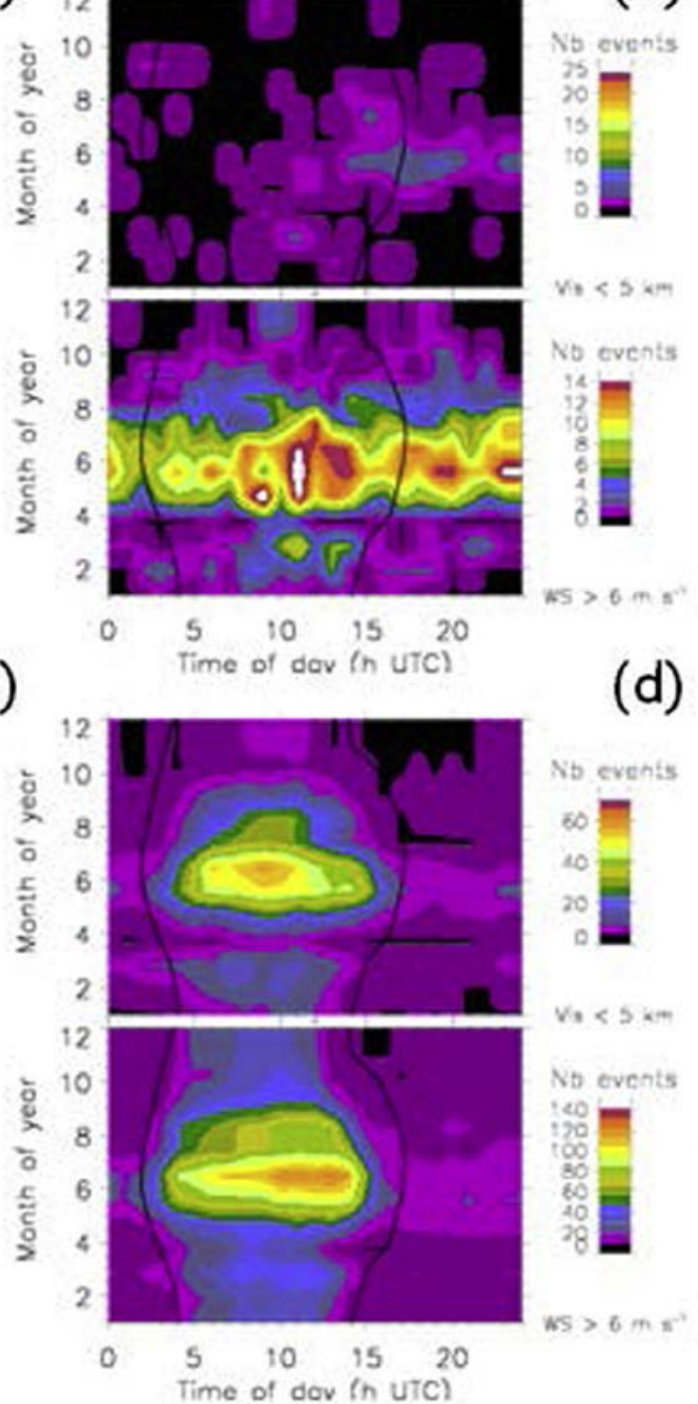
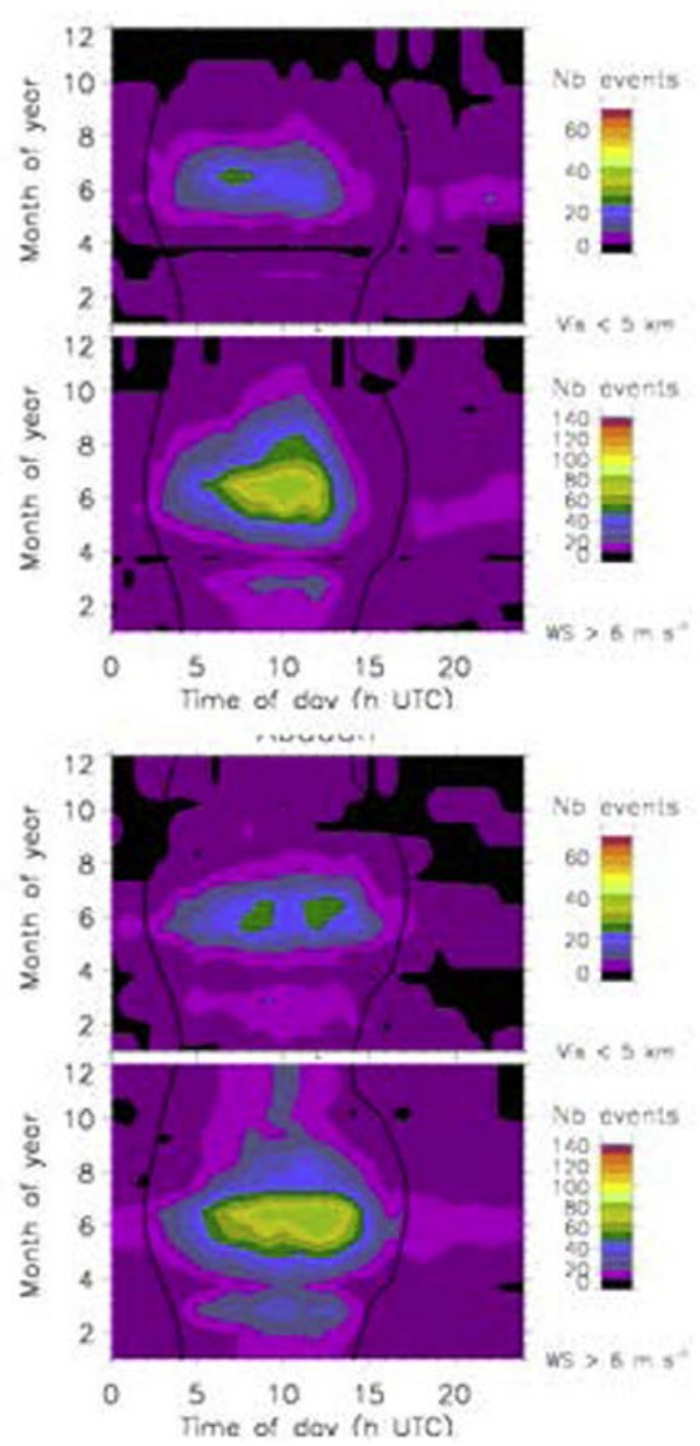

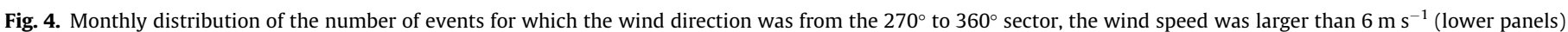

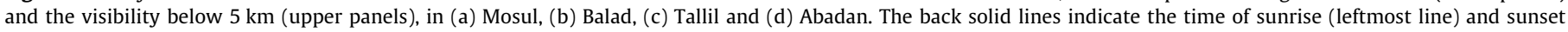
(rightmost line). 


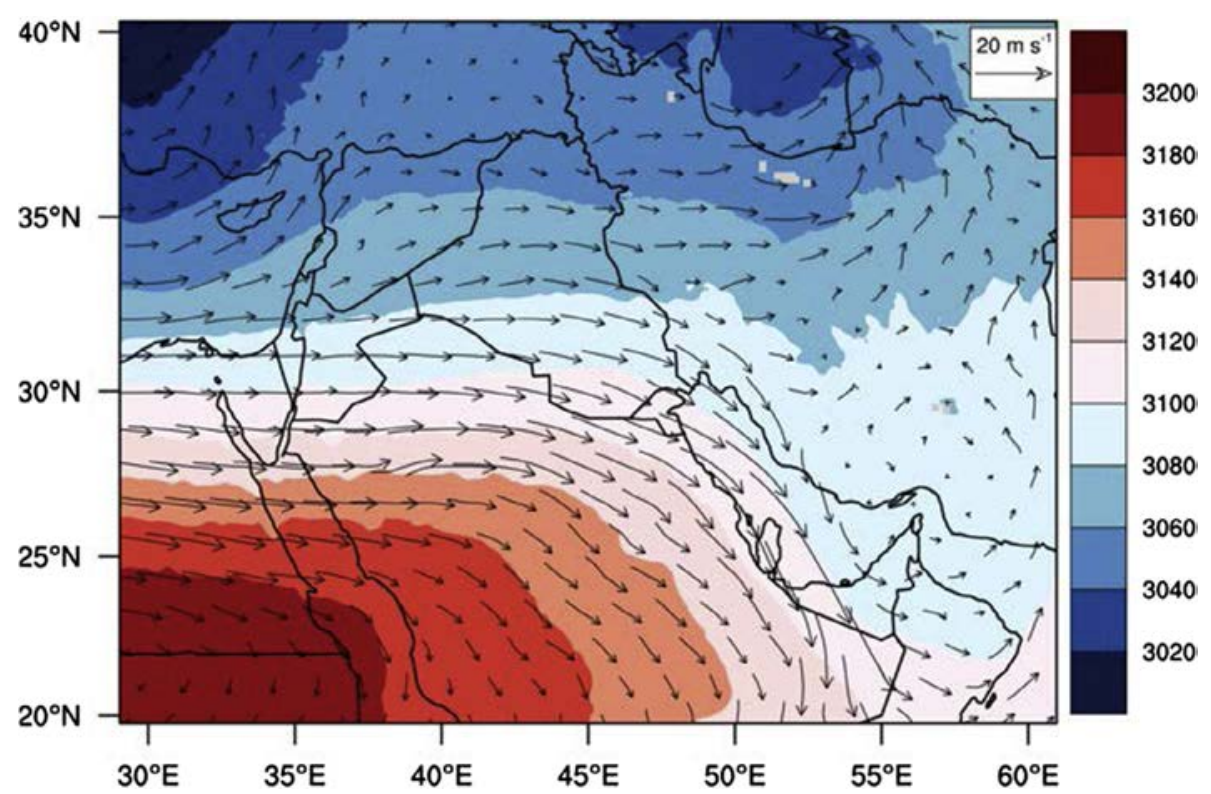

Fig. 5. Geopotential height ( $\mathrm{m}$, color) and winds (vectors) at $700 \mathrm{hPa}$ over the area of interest on 25 June 2010 at 1200 UTC.
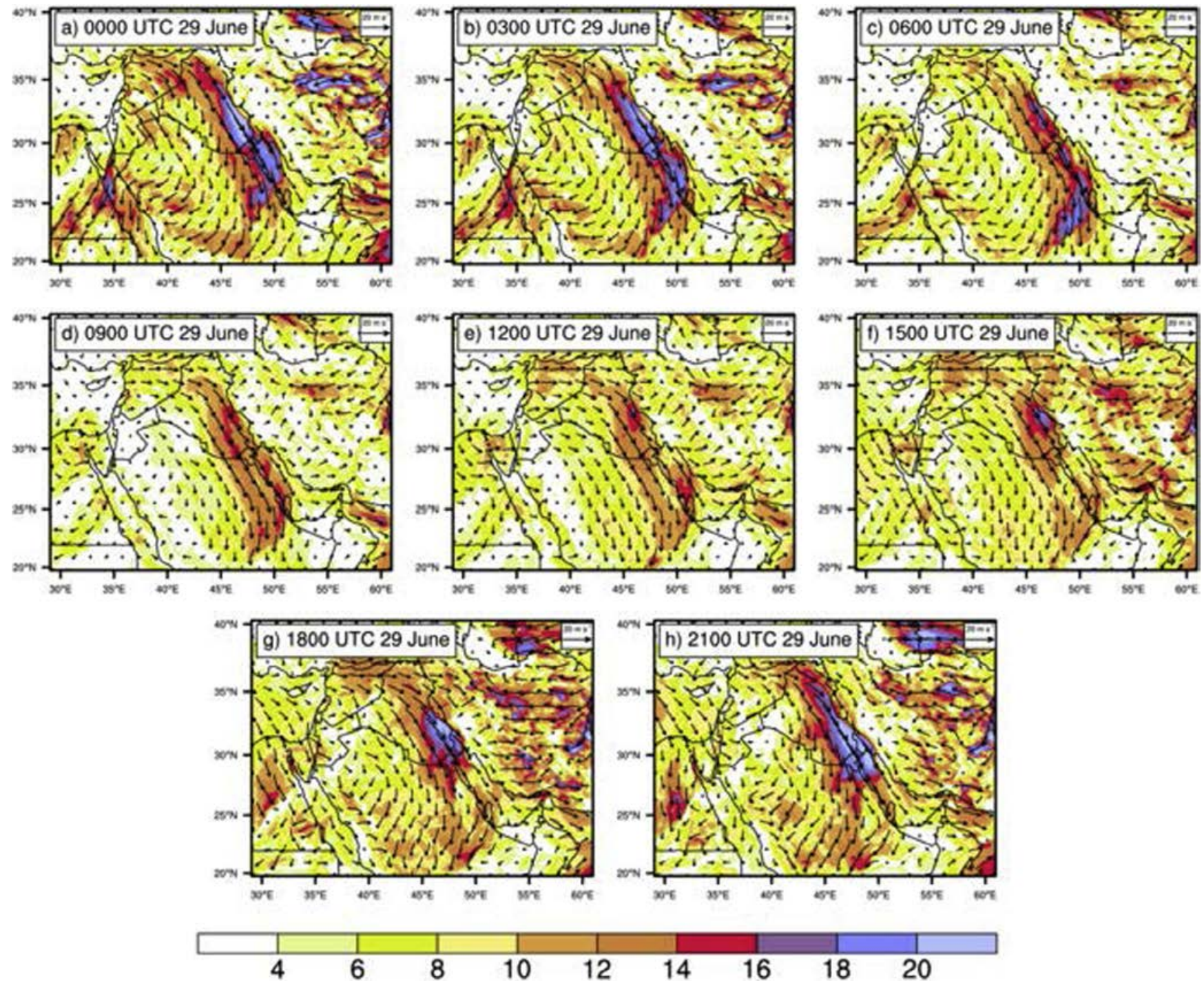

Fig. 6. Meso-NH wind speed (color, in $\mathrm{m} \mathrm{s}^{-1}$ ) and direction (vectors) at $500 \mathrm{~m}$ agl showing the evolution of the low-level jet over the Persian Gulf area on $29 \mathrm{June} 2010$ at (a) 0000, (b) 0300, (c) 0600, (d) 0900, (e) 1200, (f) 1500, (g) 1800, (h) 2100 UTC. 
ward transfer of momentum from the Shamal-related LLJ to the surface due to turbulent mixing after the onset of solar heating, as in the Bodélé depression area (Chad) (Washington et al., 2006; Todd et al., 2008). For instance, distributions of events similar to the one observed in Tallil are obtained for Balad (central Iraq, Fig. 4b) and Abadan (southern Iran, Fig. 4d). Note that we have analyzed data from many more stations than those shown in Fig. 4, but we chose not to show them all for the sake of conciseness. In Mosul, the number of high wind speed events is seen to spread more or less evenly throughout the day for the period May-July (Fig. 4a), and to be maximum around 1000 UTC. In Mosul, very few low visibility events are observed (5 events or less) likely reflecting a lack of dust source.

Furthermore, observations in Northwest Africa have highlighted the fact that the LLJ related dust emissions generally occurred between 0900 and 1200 LT (Schepanski et al., 2009), before the overpass time of MODIS on AQUA (Schepanski et al., 2012; Kocha et al., 2013), meaning that most dust plumes associated with LLJ dynamics are detected by MODIS (Schepanski et al., 2009, 2012). Over Iraq, the MODIS on AQUA overpass (1230 UTC) occurs after or during the maximum of dust mobilization as shown in Fig. 4 for Balad, Tallil and Abadan. Therefore, the large monthly averaged AOD values observed in Fig. 3 around 1230 UTC over Iraq in the spring and early summer are consistent with dust emissions related to the existence of a quasi-permanent Shamal-related LLJ (and the large near surface wind speeds associated with turbulent downward momentum transport). On the other hand, the lack of large monthly mean AODs during the rest of the year suggest more sporadic high near surface wind episodes, consistent with the frontal nature of the winter Shamal (Abdi Vishkaee et al., 2012) and the fact that only few such events are observed per month during the winter. These results are consistent with those found by Yu et al (2016), whom investigated the correlation between Shamal event frequency and dust activity on the climatology and interannual time scales and concluded that the summer dust activities in Iraq are often triggered by Shamal.

\section{The 25 June-3 July 2010 case study}

In this section we investigate the connection between the diurnal cycles of the Shamal-related LLJ, surface wind speed and dust emission in the summer, using the meso-NH simulation and satellite and ground based observations. The 25 June- 3 July case was selected as a representative case of Shamal-related LLJ during the period most favorable to dust emission due to the dry soil conditions and low rainfall probability. During this period, a strong LLJ
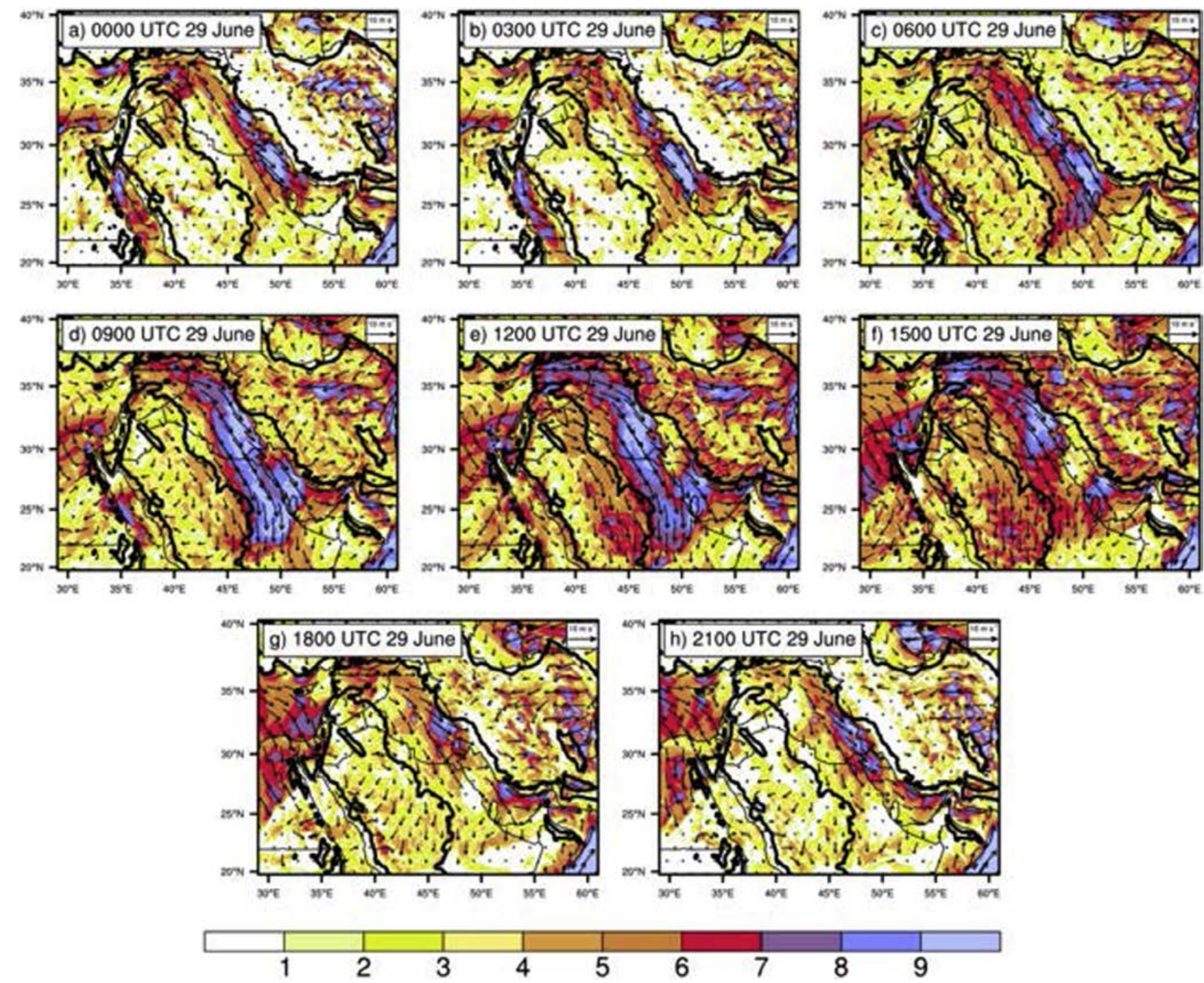

Fig. 7. Same as Fig. 6, but for $10-\mathrm{m}$ winds. The black thick line shows the $500-\mathrm{m}$ altitude. 
developed over Syria, Iraq and the Persian Gulf from 27 June onward.

\subsection{Synoptic setting}

The northwesterly winds associated with the Shamal occur as a result of the interaction of two circulating pressure centers: the low pressure cell over Iran and a semi-permanent high over northwestern Saudi Arabia and northeastern Africa (Ali, 1994). This typical pattern is shown at $700 \mathrm{hPa}$ for 25 June at 1200 UTC in Fig. 5. The resultant strong north-to-south pressure gradients give birth to the Shamal winds. The compaction of the east-west pressure gradient along the Zagros Mountains further intensifies these winds while restricting them to the western Persian Gulf (e.g. Rao et al., 2001b).

\subsection{Shamal dynamics}

Fig. 6 shows the evolution of the intensity of the LLJ (wind at $500 \mathrm{~m} \mathrm{agl}$ ) on 29 June 2010 from 0000 to 2100 UTC (note that the discussion on 29 June holds for any of the other days of the 27 June-2 July period). The LLJ is seen to be strongest before
0600 UTC and after 1800 UTC, the mean direction of the LLJ being parallel to the main axis of Zagros Mountains ridge (Fig. 1) but located along its foothills. The Shamal direction is almost constant throughout the day. The strongest winds are seen over southern Iraq, the Persian Gulf and eastern Saudi Arabia. The 10-m winds (Fig. 7) show an opposite trend, with the strongest surface winds over southeastern Iraq during daytime. High surface winds (i.e. in excess of $7 \mathrm{~m} \mathrm{~s}^{-1}$ ) can be identified over southern Iraq as early as 0600 UTC (Fig. 7c). At 0900, 1200 and 1500 UTC (Fig. 7d-f), high surface winds cover a large portion of the region of interest with a nearly contiguous area of winds in excess of $7 \mathrm{~m} \mathrm{~s}^{-1}$ from the Syria/Iraq border to Saudi Arabia. Note that the strong surface winds appear to also be constrained by the orography (see thick black isolines in Fig. 7, corresponding to $500 \mathrm{~m}$ amsl. There is also evidence of high surface winds over southeastern Iraq until 2100 UTC (Fig. 7h). At night (0000 and 0300 UTC, Fig. 7a and b), high surface winds are only seen over the Persian Gulf.

\subsection{Dust emission in connection with the Shamal}

As a result of the strong surface winds, dust emissions (Fig. 8) over southern Iraq begin at 0600 UTC in the area of Tallil, as well
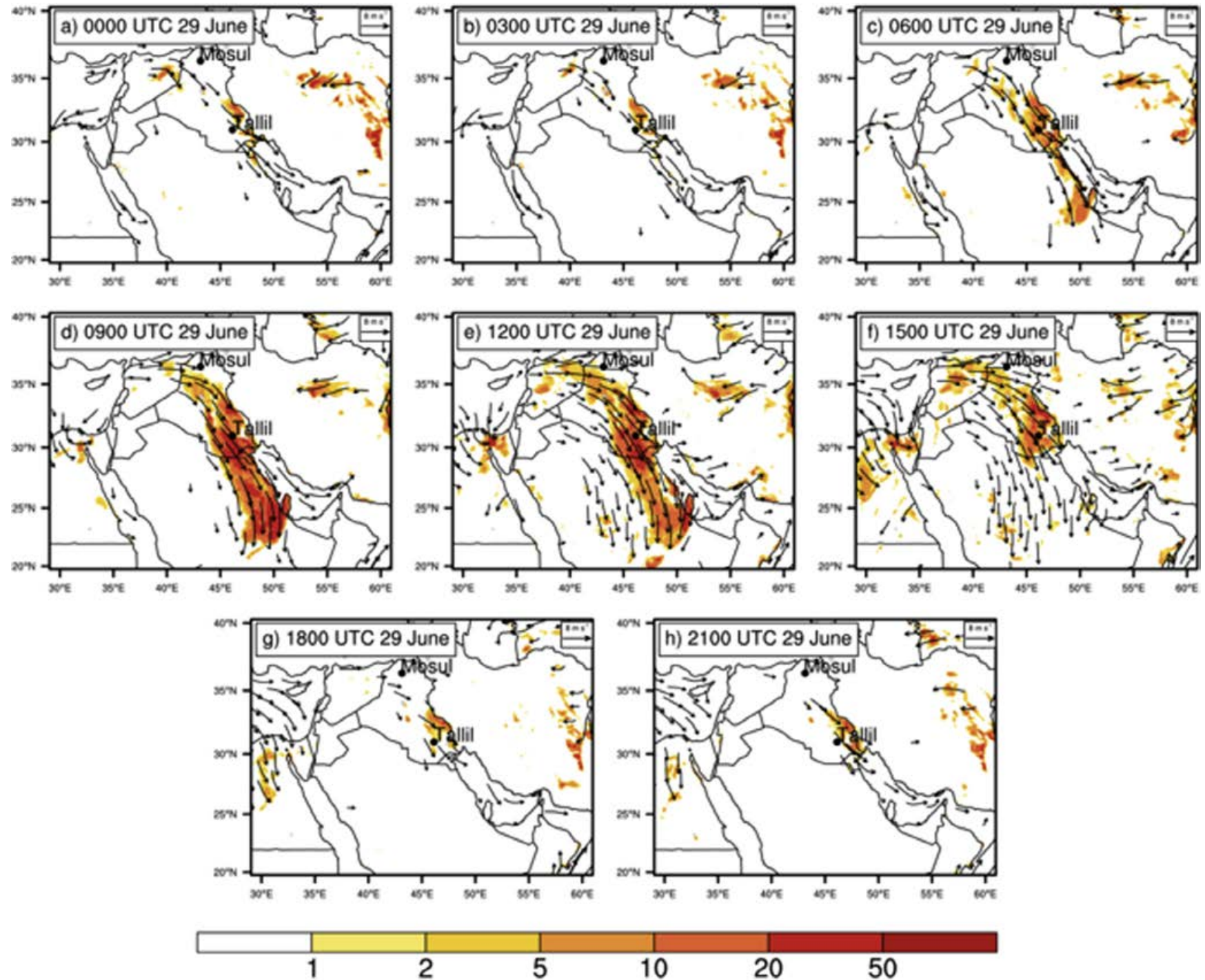

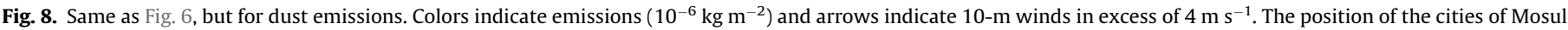
and Tallil are indicated. 
as over Qatar and the United Arab Emirates (Fig. 8c). Dust emissions over Iraq are most widespread at 0900, 1200 and 1500 UTC (Fig. $7 \mathrm{~d}-\mathrm{f}$ ). The area where the strongest emissions are observed encompass the SYNOP stations of Tallil and Balad. Weaker emissions are seen in the region of Mosul further north, Mosul being north of the main corridor of strong surface winds. At 1800 and 2100 UTC, sporadic dust emissions are seen in the vicinity of Tallil (Fig. $8 \mathrm{~g}$ and $\mathrm{h}$ ). Almost no dust sources are activated at 0000 and 0300 UTC (Fig. 8a and b).

Fig. 9 shows time-altitude cross-section of horizontal wind speed and dust concentration in Mosul, Tallil and over Saudi Arabia from 25 June to 5 July 2010, as simulated with meso-NH. In Mosul, the northwesterly Shamal LLJ is clearly distinguishable (winds in excess in the $12-16 \mathrm{~m} \mathrm{~s}^{-1}$ range), its core being center around 0000 UTC and 500 amsl between 27 June and 2 July (Fig. 9a). The surface wind speeds associated with the well-defined LLJ do not exceed $6 \mathrm{~m} \mathrm{~s}^{-1}$. On these days, meso-NH simulates light dust mobilization events (characterized by maximum concentrations on the order of $500 \mu \mathrm{g} \mathrm{m}^{-3}$ or less, Fig. 8b) shortly after the LLJ disappears, i.e. between 0000 and 0600 UTC. The low level strong winds for the period 3-5 July are simulated to be associated with a southwesterly flow (not shown), and hence not to be related to Shamal. The strongest dust concentrations in the PBL are observed on those days (Fig. 9b). On 30 June an elevated core of strong northwesterly winds is seen between 2 and $3 \mathrm{~km}$ amsl between 0000 and 1200 UTC. This feature eventually disappears after the PBL is fully developed and PBL turbulence transfers momentum downward towards the surface. This leads to dust emission in the afternoon of 30 June on the order of $500 \mu \mathrm{g} \mathrm{m}^{-3}$. A similar, albeit weaker, phenomenon is observed on 1 July.

In Tallil, the nocturnal Shamal LLJ is characterized by strong winds (in excess of $16 \mathrm{~m} \mathrm{~s}^{-1}$, Fig. 9c) at 500 amsl around 0000
UTC, embedded in a 2-3 km deep northwesterly flow, for most of the period under scrutiny. Unlike in Mosul, the flow in Tallil is exclusively from the northwest throughout the period. The strongest surface winds (in excess of $12 \mathrm{~m} \mathrm{~s}^{-1}$ ) are simulated around 1200 UTC, every day from 27 June to 3 July, and are associated with a large surface dust concentration (in excess of $3000 \mu \mathrm{g} \mathrm{m}^{-3}$, Fig. 9d). These large concentrations tend to be mixed throughout the depth of the PBL around this time. From Fig. 9d, it also appears that dust emissions are centered on 1200 UTC, but begin earlier as for instance highlighted in Fig. 8 where strong emissions are seen from 0600 UTC on, the strongest emissions occurring between 0900 and 1500 UTC. This is further analyzed in the following, using surface SYNOP observations.

In $24^{\circ} \mathrm{N}, 48^{\circ} \mathrm{E}$, i.e. in a region of Saudi Arabia affected by the Shamal winds (as shown in Fig. 7), the nocturnal Shamal-related LLJ is characterized by strong winds (in excess of $12 \mathrm{~m} \mathrm{~s}^{-1}$, Fig. 9e) at 500 amsl around 0000 UTC from 28 to 31 June only. As in Tallil, the strongest dust concentrations are seen on these days (Fig. 9f) to mix throughout the depth of the PBL. According to Fig. 8, emissions in this region occur between 0600 and 1200 UTC

Fig. 10 shows $10-\mathrm{m}$ wind speed and direction, $2-\mathrm{m}$ temperature, ratio and horizontal visibility observed at the SYNOP stations which location is given in Table 1 . All stations, with the notable exception of Mosul, experienced low visibility conditions for at least 4 consecutive days (e.g. Balad) and up to 7 consecutive days (e.g. Tallil) during the period of interest. For the three southernmost stations, the minimum value of surface horizontal visibility is observed just before 1200 UTC (15 LT), and are connected with maximum wind speed values observed daily, which suggest a maximum of dust emissions at this time, consistently with the simulations (i.e. Fig. 8). SYNOP observations also confirm that the local emissions do begin before 1200 UTC, with low visibility values
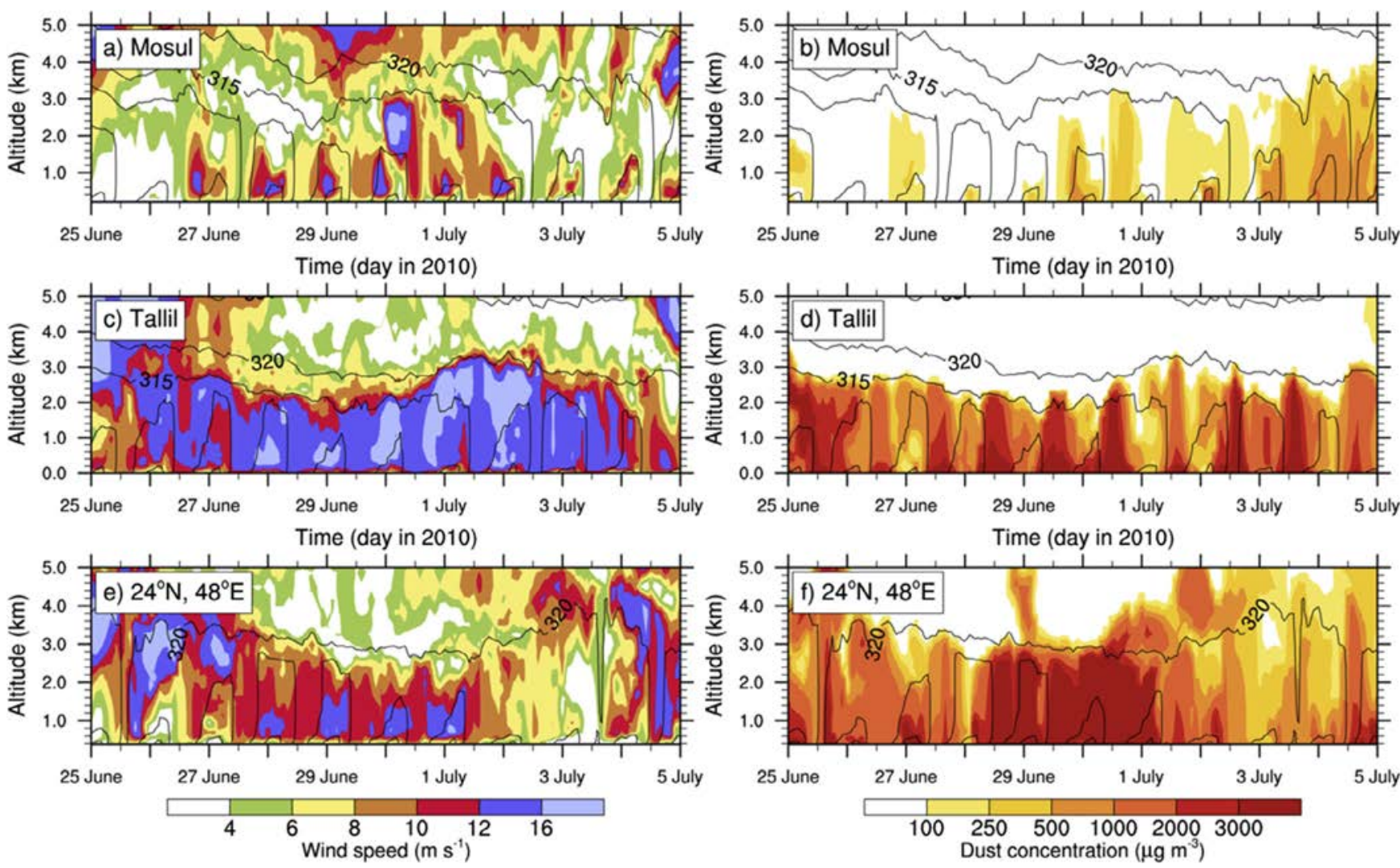

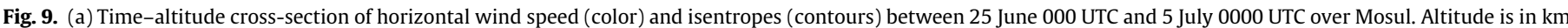

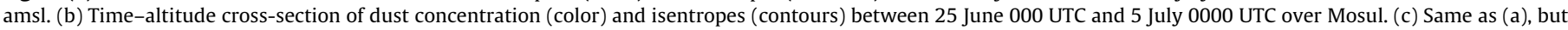
over Tallil. (d) Same as (b), but over Tallil. (e) Same as (a), but in $24^{\circ} \mathrm{N} / 48^{\circ} \mathrm{E}$ over Saudi Arabia. (f) Same as (b), but in $24^{\circ} \mathrm{N} / 48^{\circ} \mathrm{E}$ over Saudi Arabia. 
(i.e. less than $2 \mathrm{~km}$ ) observed as early as 0600 UTC (see Tallil for instance, Fig. 10c) while surface wind speeds are in excess of $7 \mathrm{~m} \mathrm{~s}^{-1}$. These results are consistent with Fig. 4 . The strong near surface wind speeds observed daily just before 1200 UTC are consistent with the idea that the maximum of turbulence-generated downward transport of momentum from the Shamal-related LLJ coincides with the maximum of surface temperature. During that period, the SYNOP data at all stations south of Mosul clearly exhibited a marked diurnal cycle in terms of the horizontal visibility that is thought to be related to the diurnal cycle of the surface winds.

The comparison between the SYNOP data and the meso-NH simulations are also shown in Fig. 10. The horizontal visibility was compared to simulated aerosol extinction at the first level of the model.

In Mosul (Fig. 10a), the simulation tends to display 2-m temperature systematically lower than observed during the 6 first days
(25-30 June), while for the following three days (1-3 July) the diurnal evolution of the $2-\mathrm{m}$ temperature is in better agreement. The near surface conditions in the simulation are also seen to be too humid with respect to the observations (not shown). In the stations further south, in Balad (Fig. 10b) and Tallil (Fig. 10c), the agreement in terms of $2-\mathrm{m}$ temperature and $10-\mathrm{m}$ winds (speed and direction) is very good. The agreement in terms of surface pressure and 2-m water vapor mixing ratio is also very good (not shown). More importantly, the model is able to simulate peaks in the near-surface extinction coefficient for the days and the times when minima of visibility are observed at these stations (Fig. 10b and c). The only notable exceptions are the peaks in extinction simulated shortly after 0000 UTC on 3 July in Balad and Tallil which are not observed. In Abadan, which is located closest to the Persian Gulf, the comparison between the simulation and the observations is good in terms of temperature and wind direc- (a)

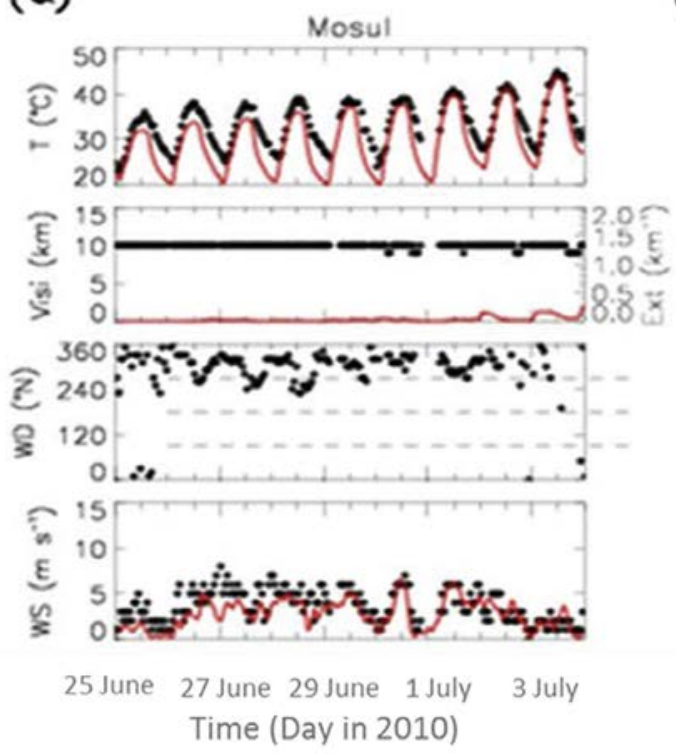

(c)

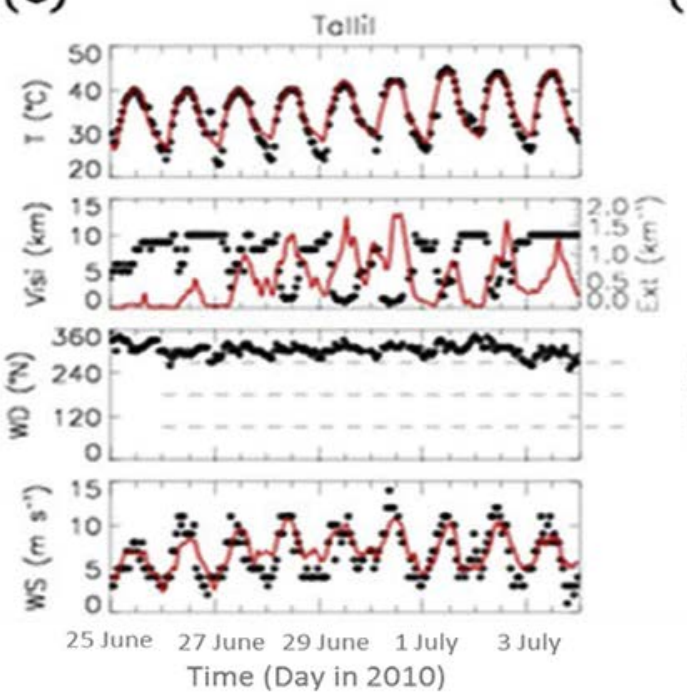

(b)

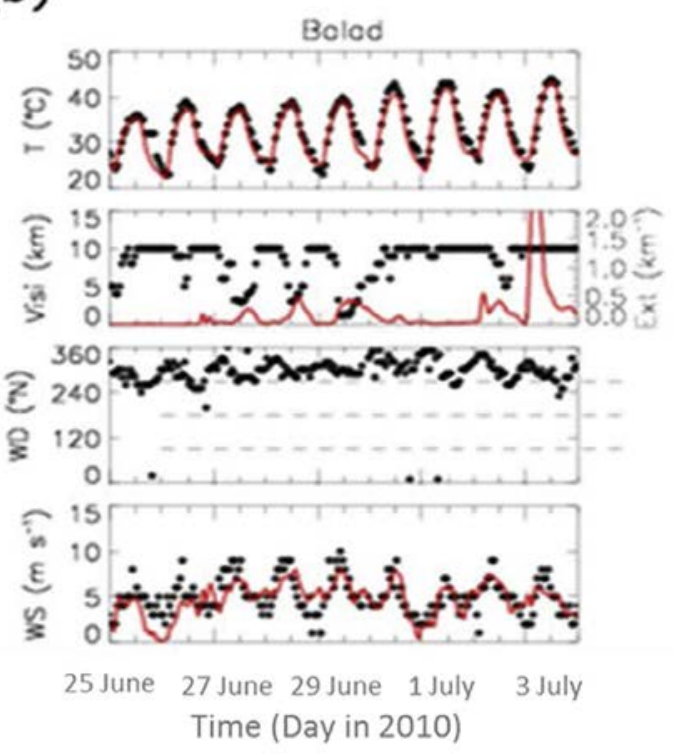

(d)

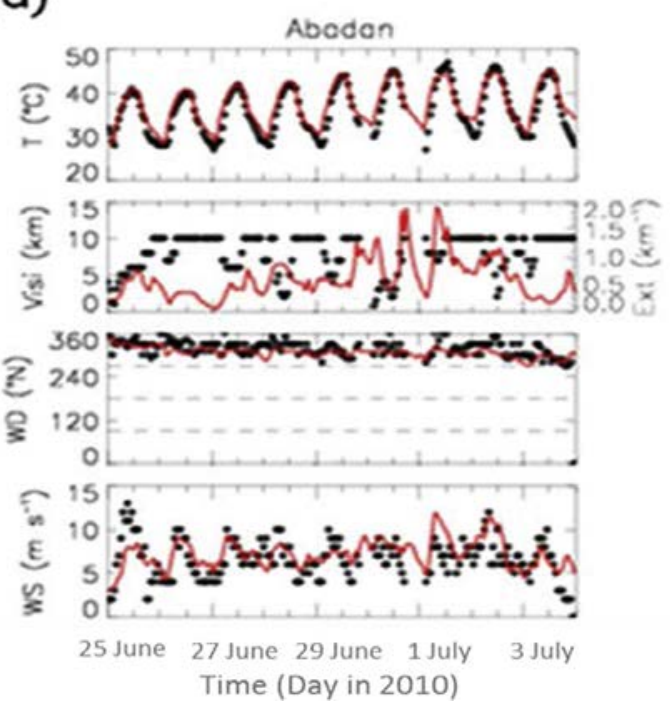

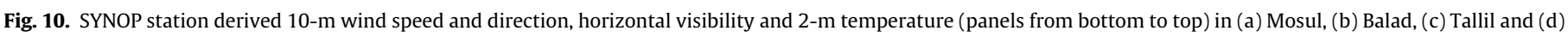

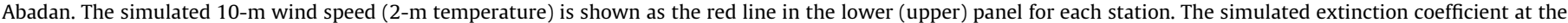

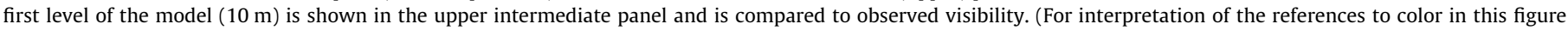
legend, the reader is referred to the web version of this article.) 
tion but not in terms of wind speed, visibility and aerosol extinction (Fig. 10d). This disagreement between the observations and the model is believed to be related to the complex land/sea breeze circulation that influence Abadan and seems not to be well represented in the simulation.

\subsection{Dust transport in connection with the Shamal}

The daily meso-NH AOD at 1200 UTC (Fig. 11) valid for the spectral band of 440-690 nm were compared against the AOD at $550 \mathrm{~nm}$ from MODIS at 1230 UTC (Fig. 12) and SEVIRI-derived AODs at 1230 UTC (Fig. 13). Over the region where the summer Shamal is blowing, a distinct arc-like feature characterized by high AOD values (in excess of 1 ) can be seen extending from southern Iraq to eastern Saudi Arabia, especially for the period from 28 June to 3 July 2010 (Fig. 11). These high AOD values are related to dust emission and transport associated with the strong Shamal winds. Similar features, with comparable intensity but less horizontal extent, are also observed in the MODIS fields on most days (Fig. 12). The most noticeable differences between meso-NH and MODIS AODs are seen over Syria (36N, 38E), Jordan (33N, 36E) and the Sinai Peninsula (30N, 35E), where MODIS consistently observes large dust aerosol loads which are generally not simulated by meso-NH and not observed in SEVIRI-derived AODs (Fig. 13). The dust plumes over Iraq seen in MODIS and meso-NH
AOD fields are generally observed in SEVIRI-derived AODs except for the areas beyond a viewing zenith angle of 70 degrees where the atmospheric path length becomes excessive (Fig. 13). Hence the infrared SEVIRI retrievals over land are not performed beyond $55^{\circ} \mathrm{E}$. Note also that SEVIRI AOD product is not available over significant areas of our domain (grey areas in Fig. 13) due to excessive cloud screening over this regions in the current version of the AOD retrievals, something to be improved in the future.

We also compare vertical cross-sections of the total dust extinction coefficient issued from both meso-NH simulations and CALIOP observations. The meso-NH dust extinction coefficient was calculated from atmospheric profiles using the LIDAR simulator developed by Chaboureau et al. (2011). We selected two CALIPSO overpasses: on 30 June at 1100 UTC (Figs. 14) and on 2 July at 1100 UTC (Fig. 15) when CALIOP overflew over eastern Iraq and sampled the vertical structure of the dust storm under scrutiny (see Figs. 14a and 15a showing the CALIPSO tracks superimposed on the meso-NH simulated AOD fields for 30 June and 2 July respectively). As shown in Fig. 14a, the CALIPSO track was mostly west of the arc-shaped dust plume, only crossing the plume on its extreme end south of $24^{\circ} \mathrm{N}$. CALIOP observations reveal a nearly constant PBL depth of about $3 \mathrm{~km}$ along the track with enhanced extinction coefficients above $0.3 \mathrm{~km}^{-1}$ south of $24^{\circ} \mathrm{N}$ (Fig. 14b) corresponding to the Shamal-related dust layer. Figs. 14b and c highlight the PBL structure just west of the region influenced by the
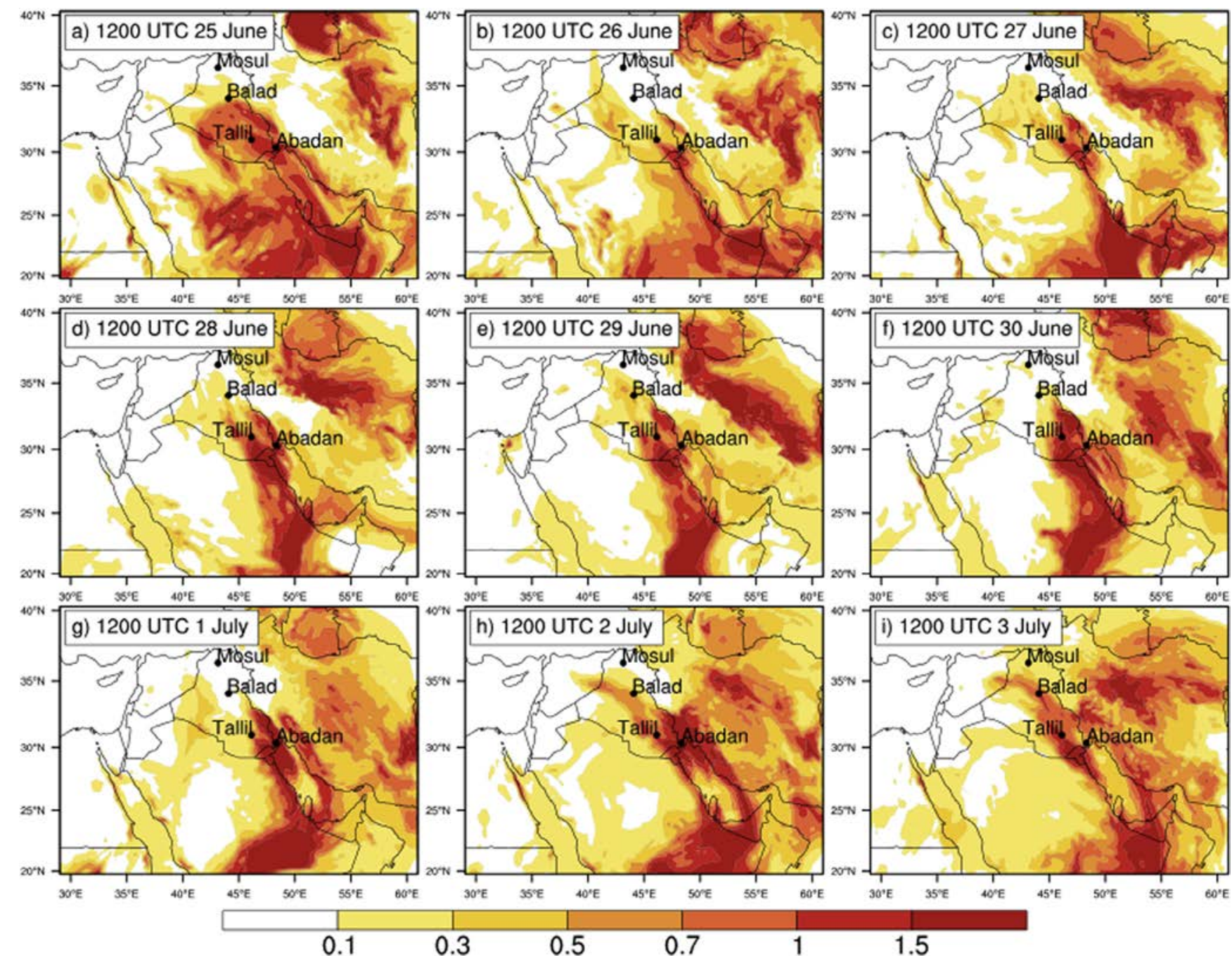

Fig. 11. Daily meso-NH AOD fields at 1200 UTC on 25 June (a), 26 June (b), 27 June (c), 28 June (d), 29 June (e), 30 June (f), 1 July (g), 2 July (h) and 3 July (i) 2010. 

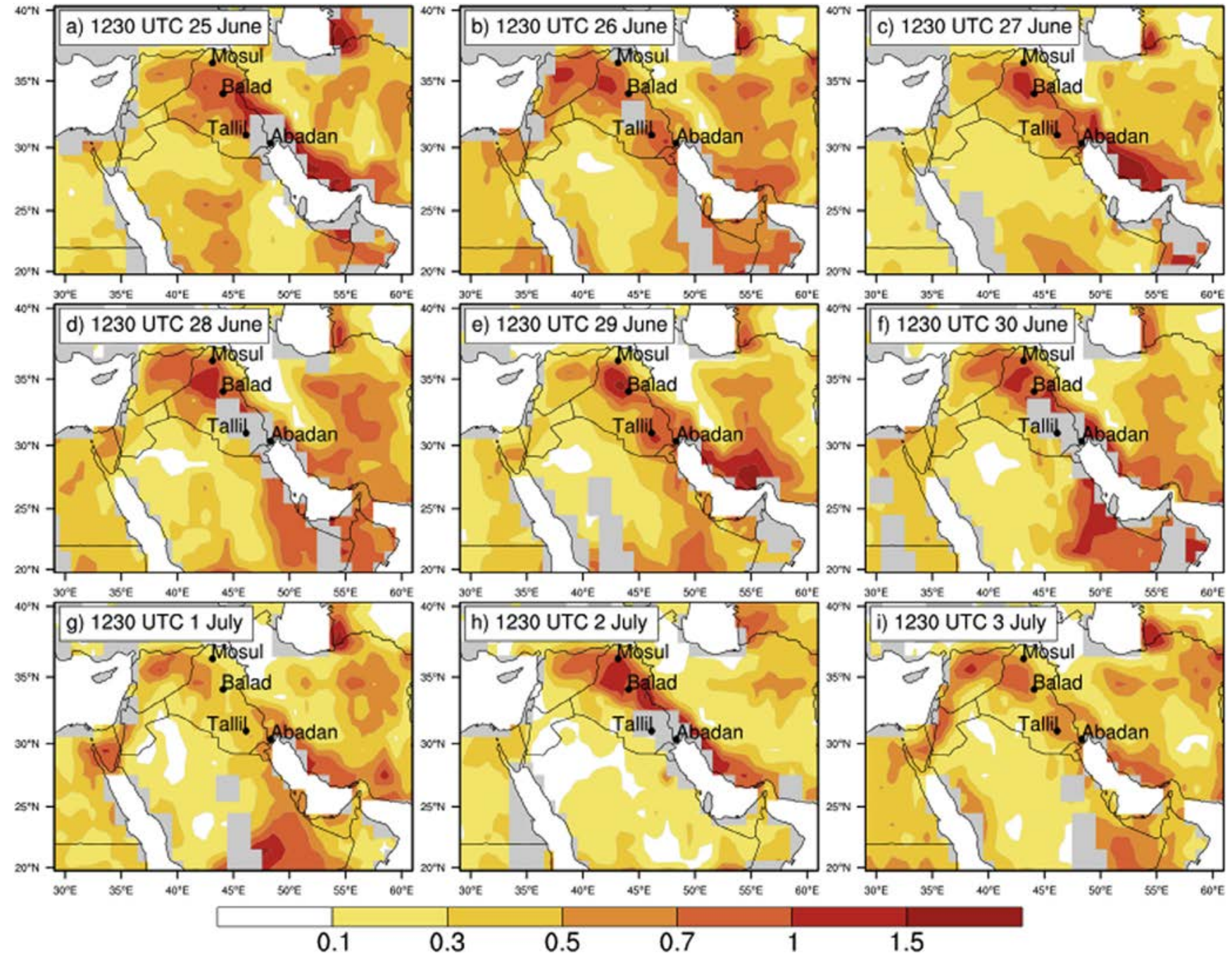

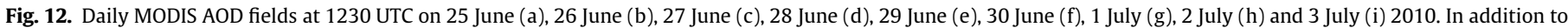
stressing out AOD less than 0.1 , grey areas indicate the presence of clouds.

Shamal (north to $24^{\circ} \mathrm{N}$ ) with associated extinction coefficients between 0.06 and $0.12 \mathrm{~km}^{-1}$. From the comparison between the AOD derived from CALIOP and simulated by meso-NH along the CALIPSO track on 30 June (Fig. 14d), we notice that the maximum in CALIOP-derived AOD around $21^{\circ} \mathrm{N}$ is missed in meso-NH simulated AODs. These high values of AOD of about 3 (Fig. 14d) are associated with the core of the dust plume (Fig. 14a) which seems to be, at the time of CALIPSO passage, already advected in the simulation to the east of the satellite track.

On 2 July the CALIPSO track is seen to cross the arc-shaped Shamal-related dust plume both over Iraq and Saudi Arabia. CALIOP nicely highlights the north-south evolution of the PBL in Fig. 15b. A rather shallow PBL (few hundred meters above ground) is observed over northern Iraq along the foothills of the Zagros Mountains of Iran. The depth of the PBL increases southwards in the direction of the main Shamal flow and reaches $3 \mathrm{~km}$ around $30^{\circ} \mathrm{N}$ where the vertical structure of the northern part of the dust plume is detected in CALIOP observations with an extinction coefficient above $0.3 \mathrm{~km}^{-1}$ (Fig. 15b). The PBL depth continues to increase while moving southward and reaches nearly $5 \mathrm{~km}$ over Saudi Arabia (between 20 and $24 \mathrm{~N}$ in Fig. 15b). The PBL structure simulated with meso-NH resembles that observed with CALIOP, with an increase of the PBL depth from north to south along the CALIOP track in the general direction of the wind (Fig. 15c). We also note the presence of PBL clouds over the Zagros Mountains as well as deep convection to the south (around $20^{\circ} \mathrm{N}$, Fig. $15 \mathrm{~b}$ and c). The dust layer seen around $30^{\circ} \mathrm{N}$ seems to be wider in the simulation than in CALIOP observations; maybe because of a small shift between the hour at which CALIPSO crossed over the plume and the nearest simulation output. This difference is also reflected in the comparison between the AODs derived from CALIOP and the simulated ones along CALIPSO track (Fig. 15d). In this comparison, we can notice the good agreement between the observations and the simulation on the AOD values attributed to the Shamal-related dust plume to be in the order of 2 (Fig. 15d). The increase in AOD in the vicinity of Tallil, in Fig. 15a, is related to an increase in extinction coefficient seen in the same region in the simulation (Fig. 15c) and in the observations (Fig. 15b). The abrupt decrease in extinction coefficient in the PBL around $31^{\circ} \mathrm{N}$ is due to the fact that the CALIOP track is no longer in the Shamal dust plume.

\subsection{Dust load associated with an episode of summer Shamal}

The estimation of the dust load associated with the Shamalrelated dust emission is derived first directly from the simulation. Its temporal evolution is estimated from 3-hourly dust concentration fields issued from meso-NH simulation, as: 

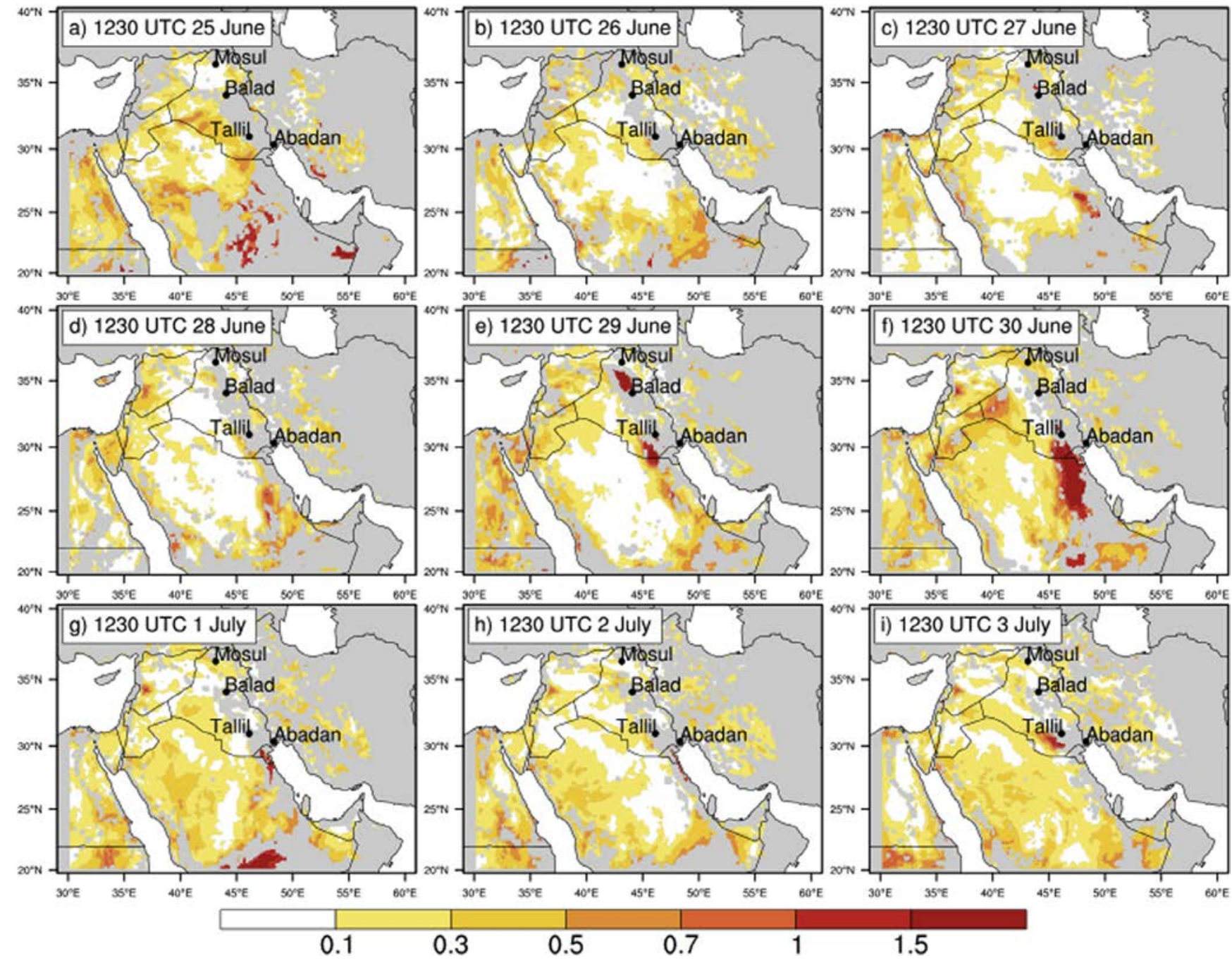

0.7

1

1.5

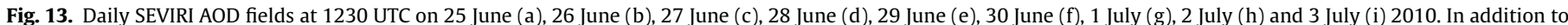
stressing out AOD less than 0.1 , grey areas correspond to non-availability of AOD data due to cloud flagging in SEVIRI-AOD retrievals.

1100 UTC 30 June 2010
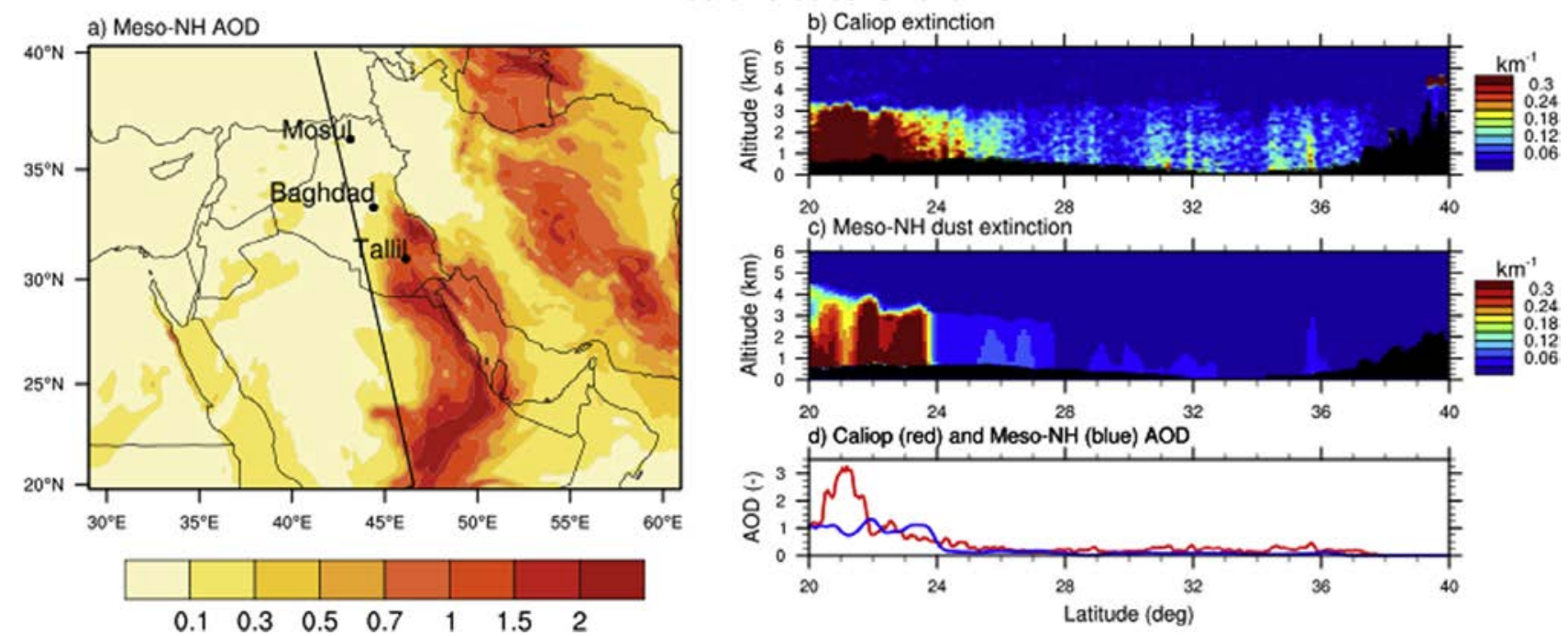

Fig. 14. (a) Meso-NH AOD field on 30 June at 1100 UTC. Superimposed is the track of the CALIPSO overpass (solid line). (b) CALIOP vertical distribution of extinction coefficient along the track shown in (a). Same as (b), but for meso-NH. (c) CALIOP and meso-NH AODs along CALIPSO track. 

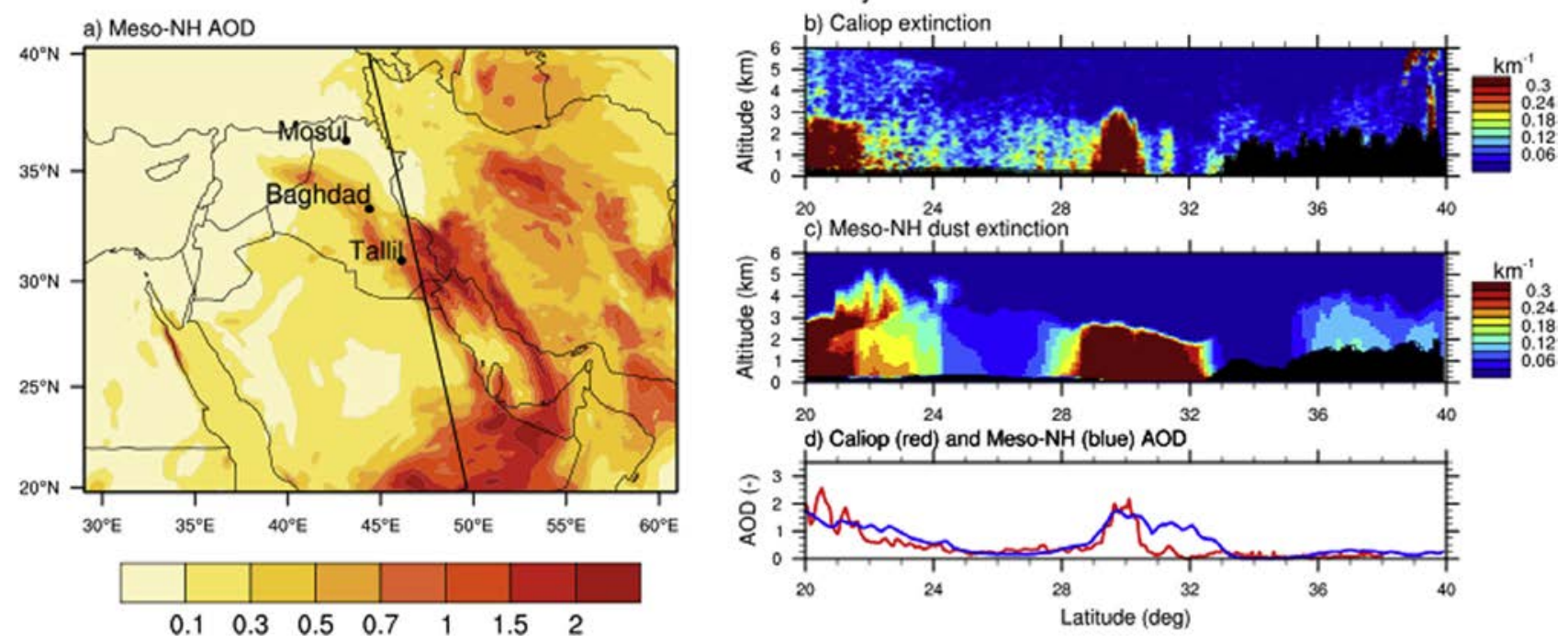

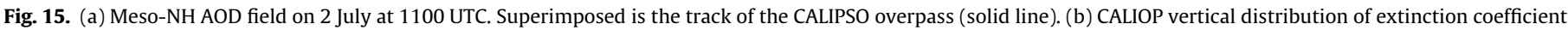
along the track shown in (a). Same as (b), but for meso-NH. (c) CALIOP and meso-NH AODs along CALIPSO track.

$\mathrm{M}_{\mathrm{s}}=\mathrm{A} \times \Sigma_{\mathrm{k}} \mathrm{C}_{\mathrm{k}} \times \Delta \mathrm{z}_{\mathrm{k}}$

where $A$ is the model domain area $\left(40-55^{\circ} \mathrm{E}, 25-35^{\circ} \mathrm{N}\right.$, i.e. the region of the Shamal), $C_{k}$ is the domain area average mean dust concentration at level $\mathrm{k}$ and $\Delta \mathrm{z}_{\mathrm{k}}$ is the depth of the layer comprised between levels k - 1 and k (Bou Karam et al., 2009b). Dust loads derived from meso-NH computed using Eq. (1) are shown in Fig. 16. The dust load exhibits large diurnal variability for the 6 days where the nighttime Shamal exhibits LLJ-like properties (28 June to 2 July), with a daily minimum value of $1 \mathrm{Tg}$ around 0600 UTC and a daily peak of 2.5 Tg or more around 1500 UTC. This is consistent with the analysis of the diurnal cycle of dust emissions and concentration derived from meso-NH (Figs. 8 and 9, respectively) and the analysis of the SYNOP data (Fig. 10). The dust load clearly appears to be driven by the Shamal winds diurnal cycle and the maximum dust load occurs shortly after the wind speed maximum observed at the surface.

In order to constrain the estimate of dust loads issued directly from the simulation, we computed dust loads from MODIS and SEVIRI derived AODs as in Koren et al. (2006):

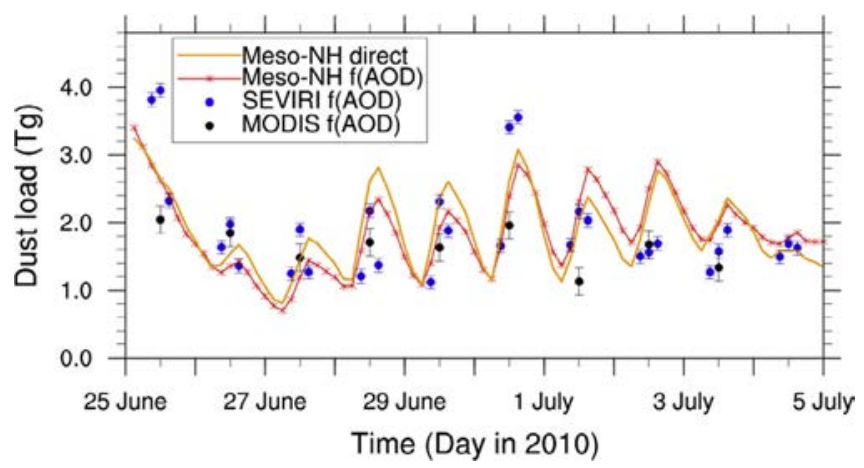

Fig. 16. Temporal evolution of the dust load computed over $40-55 \mathrm{E}$ and $25-35 \mathrm{~N}$ : From model-derived total dust concentrations using Eq. (1) between the ground and $3000 \mathrm{~m}$ agl (orange line); from model-derived AODs using Eq. (2) (red line and asterisks), from MODIS-derived AODs using Eq. (2) (black filled circles), and from SEVIRI-derives AODs using Eq. (2) (blue filled circles). SEVIRI observation over the study area are only available from 06 UTC to 14 UTC daily and they are averaged over $3 \mathrm{~h}$ to correspond to the 3-hourly model outputs. The uncertainty associated with the dust loads derived from MODIS and SEVIRI AODs is presented by the error bars in black and blue respectively. (For interpretation of the references to color in this figure legend, the reader is referred to the web version of this article.)
$\mathrm{M}_{0}=\mathrm{A} \times \mathrm{F} \times \sigma$

where $A$ is the model domain area, $\sigma$ is the mean dust AOD average over the domain area and $\mathrm{F}$ is a coefficient to be determined. To do so, we used the model derived AODs in Eq. (2) and set the coefficient $\mathrm{F}$ to $4.0 \mathrm{~g} \mathrm{~m}^{-2}$, in order for the dust load derived from this equation to be as close as possible to those derived from Eq. (1). Having the value of $\mathrm{F}$ over $40-55 \mathrm{E}$ and $25-35 \mathrm{~N}$, we computed the dust loads from MODIS and SEVIRI AODs using Eq. (2) over the same domain. The temporal evolution of the computed dust loads during the period 25 June-5 July is shown in Fig. 16. The uncertainty associated with the dust loads derived from MODIS and SEVIRI AODs is on the order of \pm 0.2 based on the uncertainty estimates for MODIS Deep blue Collection detailed in Sayer et al., 2013 and on the order of \pm 0.1 for SEVIRI based on the uncertainty estimate in Banks et al., 2013.

As expected the dust loads obtained using meso-NH-derived AODs in Eq. (2) are quite consistent with those obtained using Eq. (1), even though slightly underestimated on some days. The dust loads derived from MODIS and SEVIRI AODs using Eq. (2) are in good agreement with their simulated counterparts for the whole period except for 25 June and 30 June 2010. For these two days the model underestimate the dust loads derived from SEVIRI by $0.2 \mathrm{Tg}$ (Fig. 16). This is likely due to the existence of dust emission observed in SEVIRI AOD fields over western Iraq and eastern Syria (Fig. 13) which are missing in the simulated AOD fields (Fig. 11). The distribution of dust sources over Syria and Western Iraq and their activation depending on weather conditions is thought to be the main reason for the model discrepancy here. We note also on the 2 nd of July that the model dust loads are overestimated by $0.3 \mathrm{Tg}$ with respect to MODIS and SEVIRI-derived values. This is related to the fact that on that day clouds were present over Tallil and surrounding area as seen in MODIS and SEVIRI observations (Figs. 12 and 13). The cloud mask applied to the AODs retrievals from satellite observations led to an underestimation of the associated dust loads with respect to the simulated ones over the same domain.

\section{Summary and conclusions}

In this study, we investigate the diurnal evolution of the summer Shamal wind (a quasi-permanent low-level northwesterly 
wind feature) and its role in dust emission and transport over Iraq, and detail the processes at play on the basis of a numerical simulation for a given, representative case study (25 June-3 July 2010), using observations and a numerical simulation performed with the mesoscale model meso- $\mathrm{NH}$. Dust emissions are associated with the downward transfer of momentum from the nocturnal Shamalrelated LLJ to the surface due to turbulent mixing after solar heating commences each day. The case study highlights that the dust load during summer Shamal events exhibits large diurnal variability, with a daily minimum value of $1 \mathrm{Tg}$ around $0600 \mathrm{UTC}$ and a daily peak of $2.5 \mathrm{Tg}$ or more around $1500 \mathrm{UTC}$, and is driven by the diurnal cycle of the near surface wind speed. This finding is consistent with those from Yu et al. (2016), which were based on ground observations from weather stations in the climatology perspective. It is important to note that the dust load peak associated with the summer Shamal is on the same order as those also derived from simulations downstream of the Bodélé depression (Chad), estimated to be on the order of $2.7 \mathrm{Tg}$ (Todd et al., 2008). Bodélé is known to be one of the most prolific dust sources on Earth.

Furthermore, near surface dust concentrations associated with these dust loads in southern Iraq (e.g. Tallil), western Iran (e.g. Abadan) and over Saudi Arabia are simulated to reach values in excess of $3000 \mu \mathrm{g} \mathrm{m}^{-3}$ for periods of 4-6 days, and also simulated to never fall below $100 \mu \mathrm{g} \mathrm{m}^{-3}$. The estimation of the dust load associated with the Shamal summer wind was computed from three independent datasets, i.e. using MODIS and SEVIRI derived AODs and directly from the simulations. The three datasets gave roughly the same estimate. In general, dust emission by Shamal winds over Iraq was well reproduced by the model. However, a better representation in dust models of dust sources in Syria, Jordan and the Sinai Peninsula especially alluvial dust sources is suggested for future studies given the nature of the dust sources in this region.

\section{Acknowledgements}

The European Centre for Medium-Range Weather Forecasts (ECMWF) is acknowledged for making the meteorological analyses available from their data server. The CALIPSO data were obtained from the ICARE Thematic Center. The CALIPSO data were obtained from the NASA Langley Research Center Atmospheric Science Data Center. MODIS AODs used in this study were produced with the Giovanni online data system, developed and maintained by the NASA Goddard Earth Sciences (GES) Data and Information Services Center (DISC). The Research Institute of NYU Abu Dhabi is thanked for supporting the research activity at the Center for Global Sea Level Change (CSLC) through grant G1204.

\section{References}

Abdi Vishkaee, F., Flamant, C., Cuesta, J., Flamant, P., Khalesifard, H., 2011. Multiplatform observations of dust vertical distribution during transport over northwest Iran in the summertime. J. Geophys. Res. 116, D05206. http://dx. doi.org/10.1029/2010JD014573.

Abdi Vishkaee, F., Flamant, C., Cuesta, J., Oolman, L., Flamant, P., Khalesifard, H.R. 2012. Dust transport over Iraq and northwest Iran associated with winter Shamal: a case study. J. Geophys. Res. 117, D03201. http://dx.doi.org/10.1029/ 2011JD016339.

Ali, A.H., 1994. Wind regime of the Arabian Gulf. In: El-Baz, F., Makharita, R.M. (Eds.), The Gulf War and the Environment. Gordon and Breach, New York, pp. $31-48$.

Banks, J.R., Brindley, H.E., 2013. Evaluation of MSG-SEVIRI mineral dust retrieval products over North Africa and the Middle East. Remote Sens. Environ. 128, 5873. http://dx.doi.org/10.1016/j.rse.2012.07.017.

Banks, J., Brindley, H., Flamant, C., Garay, M., Hsu, N., Kalashnikova, O., Klüser, L., Sayer, A., 2013. Intercomparison of satellite dust retrieval products over the West African Sahara during the Fennec campaign in June 2011. Remote Sens. Environ. 136, 99-116.

Bechtold, P., Bazile, E., Guichard, F., Mascart, P., Richard, E., 2001. A mass flux convection scheme for regional and global models. Q. J. R. Meteorol. Soc. 127, 869-886.
Blackadar, A.K., 1957. Boundary-layer wind maxima and their significance for the growth of nocturnal inversions. Bull. Am. Meteorol. Soc. 38, 283-290.

Bou Karam, D., Flamant, C., Knippertz, P., Reitebuch, O., Pelon, J., Chong, M., Dabas A., 2008. Dust emissions over the Sahel associated with the West African Monsoon inter-tropical discontinuity region: a representative case study. Q. J. R. Meteorol. Soc. 134, 621-634.

Bou Karam, D., Flamant, C., Knippertz, P., Reitebuch, O., Pelon, J., Chong, M., Dabas A., 2009a. Dry cyclogenesis and dust mobilization in the Inter Tropical Discontinuity of the West African Monsoon: a case study. J. Geophys. Res. 114, D05115. http://dx.doi.org/10.1029/2008JD010952.

Bou Karam, D., Flamant, C., Tulet, P., Chaboureau, J.-P., Dabas, A., Todd, M.C., 2009b. Estimate of Sahelian dust emissions in the inter-tropical discontinuity region of the West African Monsoon. J. Geophys. Res. 114, D13106. http://dx.doi.org/ 10.1029/2008JD011444.

Bou Karam, D., Flamant, C., Cuesta, J., Pelon, J., Williams, E., 2010. Dust emission and transport associated with a Saharan depression: the February 2007 case. J. Geophys. Res. http://dx.doi.org/10.1029/2009JD012390.

Bou Karam, D., Williams, E., Janiga, M., Flamant, C., McGraw-Herdeg, M., Cuesta, J. Auby, A., Thorncroft, C., 2014. Synoptic-scale dust emissions over the Sahara Desert initiated by a moist convective cold pool in early August 2006. Q. J. Roy. Meteor. Soc. 140, 2591-2607. http://dx.doi.org/10.1002/qj.2326.

Brindley, H.E., 2007. Estimating the top-of-atmosphere longwave radiative forcing due to Saharan dust from satellite observations over a West African surface site. Atmos. Sci. Lett. 8, 74-79. http://dx.doi.org/10.1002/asl.155.

Brindley, H.E., Russell, J.E., 2009. An assessment of Saharan dust loading and the corresponding cloud-free longwave direct radiative effect from geostationary satellite observations. J. Geophys. Res. 114. http://dx.doi.org/10.1029/ 2008JD011635.

Chaboureau, J.-P., Bechtold, P., 2002. A simple cloud parameterization derived from cloud resolving model data: diagnostic and prognostic applications. J. Atmos. Sci. 59, 2362-2372.

Chaboureau, J.-P., Bechtold, P., 2005. Statistical representation of clouds in a regional model and the impact on the diurnal cycle of convection during Tropical Convection, Cirrus and Nitrogen Oxides (TROCCINOX). J. Geophys. Res. 110, D17103. http://dx.doi.org/10.1029/2004JD005645.

Chaboureau, J.-P., Richard, E., Pinty, J.-P., Flamant, C., Di Girolamo, P., Kiemle, C. Behrendt, A., Chepfer, H., Chiriaco, M., Wulfmeyer, V., 2011. Long-range transport of Saharan dust and its radiative impact on precipitation forecast over Western Europe: a case study during the Convective and Orographically induced Precipitation Study (COPS). Q. J. R. Meteorol. Soc. 137, 236-251.

Crumeyrolle, S., Tulet, P., Gomes, L., Garcia-Carreras, L., Flamant, C., Parker, D.J., Matsuki, A., Formenti, P., Schwarzenboeck, A., 2011. Transport of dust particles from the Bodélé region to the monsoon layer - AMMA case study of the 9-14 June 2006 period. Atmos. Chem. Phys. 11, 479-494.

Cuesta, J., Marsham, J.H., Parker, D.J., Flamant, C., 2009. Dynamical mechanisms controlling the vertical redistribution of dust and the thermo-dynamic structure of the West Saharan Atmospheric Boundary Layer during summer. Atmos. Sci. Lett. 10 (1), 34-42.

Cuxart, J., Bougeault, Ph., Redelsperger, J.L., 2000. A turbulence scheme allowing for mesoscale and large-eddy simulations. Q. J. R. Meteorol. Soc. 126, 1-30.

Dee, D.P. et al., 2011. The ERA-Interim reanalysis: configuration and performance of the data assimilation system. Q. J. R. Meteorol. Soc. 137, 553-597. http://dx.doi. org/10.1002/qj.828.

Derrien, M., Le Gléau, H., 2005. MSG/SEVIRI cloud mask and type from SAFNWC. Int J. Remote Sens. 26, 4707-4732. http://dx.doi.org/10.1080/01431160500166128.

Giannakopoulou, E.M., Toumi, R., 2011. The Persian Gulf summertime low-level jet over sloping terrain. Q. J. R. Meteorol. Soc. 138, 145-157. http://dx.doi.org/ 10.1002/qj.901.

Grini, A., Tulet, P., Gomes, L., 2006. Dusty weather forecasts using the MesoNH mesoscale atmospheric model. J. Geophys. Res. 111, D19205. http://dx.doi.org/ 10.1029/2005JD007007.

Hsu, N.C., Tsay, S.-C., King, M.D., Herman, J.R., 2004. Aerosol properties over brightreflecting source regions. IEEE Trans. Geosci. Remote Sens. 42 (3), 557-569.

Koren, I., Kaufman, Y.J., Washington, R., Todd, M.C., Rudich, Y., Martins, J.V., Rosenfeld, D., 2006. The Bodélé depression: a single spot in the Sahara that provides most of the mineral dust to the Amazon forest. Environ. Res. Lett. 1 014005. http://dx.doi.org/10.1088/1748-9326/1/1/014005.

Kocha, C., Tulet, P., Lafore, J.-P., Flamant, C., 2013. The importance of the diurna cycle of aerosol optical thickness in West Africa. Geophys. Res. Lett. 40 (4), 785 790. http://dx.doi.org/10.1002/grl.50143.

Kok, J.F., Parteli, E.J.R., Michaels, T.I., Bou, Karam D., 2012. The physics of wind blown sand and dust. Rep. Prog. Phys. 75, 106901.

Lafore, J.P., Stein, J., Asencio, N., Bougeault, P., Ducrocq, V., Duron, J., Fischer, C. Hereil, P., Mascart, P., Pinty, J.P., Redelsperger, J.L., Richard, E., Vila-Guerau de Arellano, J., 1998. The Meso-NH atmospheric simulation system. Part I: adiabatic formulation and control simulations. Scientific objectives and experimental design. Ann. Geophys. 16, 90-109.

Liu, M., Westphal, D.L., Walker, A., Holt, T., Richardson, K., Miller, S., 2007. COAMPS Real-time dust storm forecasting during operation iraqi freedom. Weather Forecasting 22, 192-206.

Mahowald, N.M., Ballentine, J.A., Feddema, J., Ramankutty, N., 2007. Global trends in visibility: implications for dust sources. Atmos. Chem. Phys. 7, 3309-3339.

Mallet, M., Tulet, P., Serça, D., Solmon, F., Dubovik, O., Pelon, J., Pont, V., Thouron, O. 2009. Impact of dust aerosols on the radiative budget, surface heat fluxes heating rate profiles and convective activity over West Africa during March 2006. Atmos. Chem. Phys. 9, 7143-7160. 
Membery, D.A., 1983. Low-level wind profiles during the Gulf Shamal. Weather 38, $18-24$.

Middleton, N., 1986a. Dust storms in the Middle East. J. Arid Environ. 10, 83-96.

Middleton, N., 1986b. A geography of dust storms in Southwest Asia. J. Clim. 6, 183 196.

Mlawer, E.J., Taubman, S.J., Brown, P.D., Iacono, M.J., Clough, S.A., 1997. Radiative transfer for inhomogeneous atmospheres: RRTM, a validated correlated-k model for the longwave. J. Geophys. Res. 102D, 16663-16682.

Mokhtari, M., Gomes, L., Tulet, P., Rezoug, T., 2012. Importance of the surface size distribution of erodible material: an improvement on the dust entrainment and deposition (dead) model. Geosci. Model Dev. 5, 581-598. http://dx.doi.org/ 10.5194/gmd-5-581.

Notaro, M., Alkolibi, F., Fadda, E., Bakhrjy, F., 2013. Trajectory analysis of Saudi Arabian dust storm. J. Geophys. Res.-Atmos. 118 (12), 6028-6043.

Notaro, M., Yu, Y., Kalashnikova, O., 2015. Regime shift in Arabian dust activity, triggered by persistent Fertile Crescent drought. J. Geophys. Res.-Atmos. 120 (19), 10229-10249.

Perrone, T.J., 1979. Winter Shamal in the Persian Gulf, Tech. Rep. TR 79-06, 168 pp. Nav. Environ. Predict. Res. Facil., Monterey, Calif.

Pinty, J.-P., Jabouille, P., 1998. A mixed-phase cloud parameterization for use in a mesoscale non-hydrostatic model: Simulations of a squall line and of orographic precipitations. In: Preprints, Conf. on Cloud Physics, Everett, WA Amer. Meteor. Soc., pp. 217-220.

Prospero, J.M., Ginoux, P., Torres, O., Nicholson, S.E., Gill, T.E., 2002. Environmental characterization of global sources of atmospheric soil dust identified with the NIMBUS 7 Total ozone mapping spectrometer (TOMS) absorbing aerosol product. Rev. Geophys. 40 (1), 1002. http://dx.doi.org/10.1029/2000RG000095.

Rao, P.G., Al-Sulaiti, M., Al-Mulla, A.H., 2001a. Winter Shamals in Qatar, Arabian Gulf. Weather 56, 444-451.

Rao, P.S.P., Momin, G.A., Safai, P.D., Ali, K., Naik, M.S., Pillai, A.G., 2001b. Aerosoland Ttrace Gas Studies at Pune DuringINDOEX IFP-99. Curr. Sci. 80, 105-109.

Sayer, A.M., Hsu, N.C., Bettenhausen, C., Jeong, M.J., 2013. Validation and uncertainty estimates for MODIS Collection 6 "Deep Blue" aerosol data. J. Geophys. Res. 118 (14), 7864-7872.

Schepanski, K., Tegen, I., Todd, M.C., Heinold, B., Bönisch, G., Laurent, B., Macke, A. 2009. Meteorological processes forcing Saharan dust emission inferred from MSG-SEVIRI observations of sub-daily dust source activation. J. Geophys. Res. 114, D10201. http://dx.doi.org/10.1029/2008JD010325.

Schepanski, K., Tegen, I., Macke, A., 2012. Comparison of satellite based observations of Saharan dust source areas. Rem. Sens. Environ. 123, 90-97. http://dx.doi.org 10.1016/j.rse.2012.03.019.

Schmetz, J., Pili, P., Tjemkes, S., Just, D., Kerkmann, J., Rota, S., et al., 2002. An introduction to meteosat second generation (MSG). Bull. Am. Meteorol. Soc. 83, 977-992.
Todd, M.C., Bou Karam, D., Cavazos, C., Bouet, C., Heinold, B., Baldasano, J.M., Cautenet, G., Koren, I., Perez, C., Solmon, F., Tegen, I., Tulet, P., Washington, R., Zakey, A., 2008. Quantifying uncertainty in estimates of mineral dust flux: an inter-comparison of model performance over the Bodélé Depression, Northern Chad. J. Geophys. Res. 113, D24107. http://dx.doi.org/10.1029/2008JD010476.

Tulet, P., Mallet, M., Pont, V., Pelon, J., Boone, A., 2008. The 7-13 March 2006 dust storm over West Africa: Generation, transport, and vertical stratification. J. Geophys. Res. 113, D00C08. http://dx.doi.org/10.1029/2008JD009871.

Tulet, P., Crassier, V., Cousin, F., Shure, K., Rosset, R., 2005. ORILAM, A three moment lognormal aerosol scheme for mesoscale atmospheric model. On-line coupling into the Meso-NH-C model and validation on the Escompte campaign. J. Geophys. Res. 110, D18201. http://dx.doi.org/10.1029/2004JD005716.

Walker, A.L., Liu, M., Miller, S.D., Richardson, K.A., Westphal, D.L., 2009. Development of a dust source database for mesoscale forecasting in southwest Asia. J. Geophys. Res. 114, D18207. http://dx.doi.org/10.1029/ 2008JD011541.

Walters, K.R., Sjoberg, W.F., 1988. The Persian Gulf Region. A Climatological Study. USAF Environmental Technical Applications Center USAFETAC/TN-88/002. Available from http://www.dtic.mil/cgi-bin/GetTRDoc?AD=ADA222654

Washington, R., Todd, M.C., 2005. Atmospheric controls on mineral dust emission from the Bodéle Depression, Chad: The role of the low level jet. Geophys. Res. Lett. 32, L17701. http://dx.doi.org/10.1029/2005GL023597.

Washington, R., Todd, M.C., Lizcano, G., Tegen, I., Flamant, C., Koren, I., Ginoux, P., Engelstaedter, S., Bristow, C., Zender, C., Goudie, A., Warren, A., Prospero, J., 2006. Links between topography, wind, deflation, lakes and dust: the case of the Bodélé depression, Chad. Geophys. Res. Lett. 33, L09401. http://dx.doi.org/ 10.1029/2006GL025827.

Wilkerson, W.D., 1991. Dust and sand forecasting in Iraq and adjoining countries, Tech. Note AWS/TN-91/001, 63 pp., Air Weather Serv., Scott AFB, Ill. Available from http://www.dtic.mil/cgi-bin/GetTRDoc?AD=ADA247588.

Winker, D.M., Hunt, W.H., McGill, M.J., 2007. Initial performance assessment of CALIOP. Geophys. Res. Lett. 34, L19803. http://dx.doi.org/10.1029/ 2007GL030135.

Yu, Y., Notaro, M., Liu, Z., Wang, F., Alkolibi, F., Fadda, E., Bakhrjy, F., 2015. Climatic controls of the interannual to decadal variability in Saudi Arabian dust activity: towards the development of a seasonal prediction model. J. Geophys. Res.Atmos. 120 (5), 1739-1758.

Yu, Y., Notaro, M., Kalashnikowa, O., Garay, M., 2016. Climatology of summer Shamal wind in the Middle East. J. Geophys. Res.-Atmos. 121 (1), 289-305.

Zender, C.S., Bian, H.S., Newman, D., 2003. Mineral dust entrainment and deposition (DEAD) model: description and 1990s dust climatology. J. Geophys. Res. 108 (D14), 4416. http://dx.doi.org/10.1029/2002JD002775. 